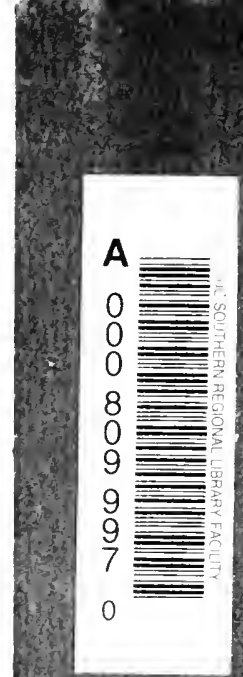

lifornia ional lity 
Diez, Juan. Sumario Compendioso; earliest mathematical work of the New World, by D. E. Smith. 1921. Facsimile text \& trans.

Facsimile text \& trans. (14ji) 


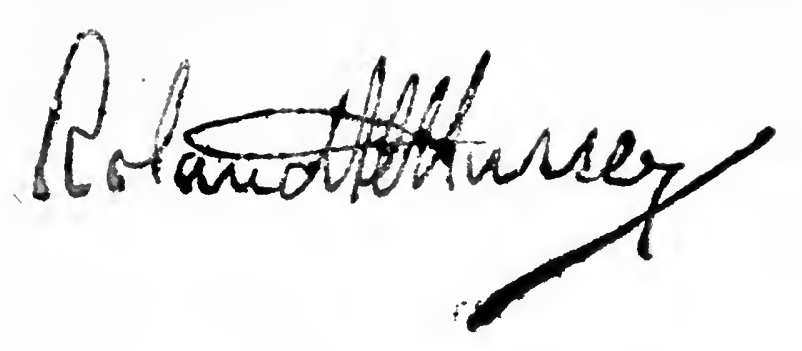



. 


\section{Digitized by the Internet Archive in 2007 with funding from Microsoft Corporation}


THE SUMARIO COMPENDIOSO . 




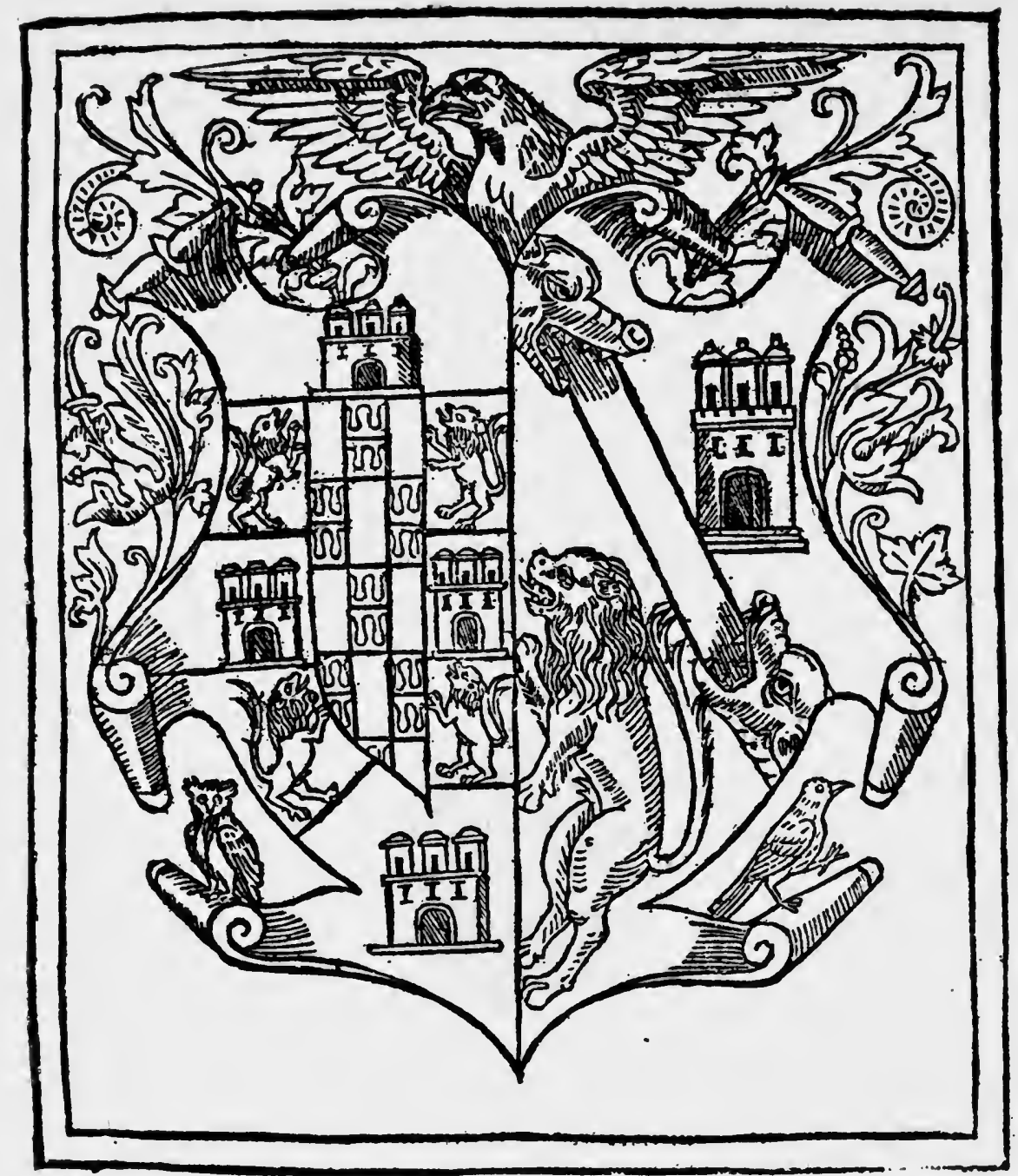

1 Sumario cốpểiofo o das quêtas

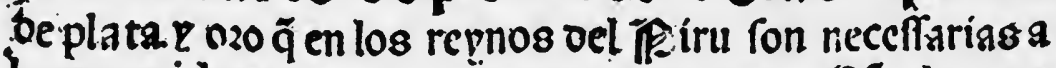
los'mercáderes: $z$ todo genero oe tratantcs. Ẽö algunas reglas tocantesal diritbinetica.

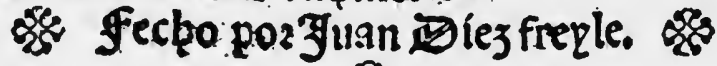
खु 


\section{THE SUMARIO COMPENDIOSO OF BROTHER JUAN DIEZ}

THE EARLIEST MATHEMATICAL WORK OF THE NEW WORLD

BY

DAVID EUGENE SMITH

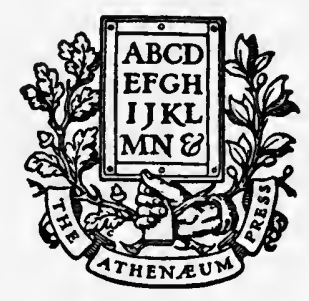

BOSTON AND LONDON

GINN AND COMPANY, PUBLISHERS MDCCCCXXI 
COPYRIGHT, 1921, BY DAVID EUGENE SMITH ALL RIGHTS RESERVED

THE ATHENAUM PRESS - CAMBRIDGE - MASSACHUSETTS - U.S.A. 


\section{PREFACE}

If the student of the history of education were asked to name the earliest work on mathematics published by an American press, he might, after a little investigation, mention the anonymous arithmetic that was printed in Boston in the year 1729 . It is now known that this was the work of that Isaac Greenwood who held for some years the chair of mathematics in what was then Harvard College. If he should search the records still farther back, he might come upon the American reprint of Hodder's well-known English arithmetic, the first textbook on the subject, so far as known, to appear in our language on this side the Atlantic. If he should look to the early Puritans in New England for books of a mathematical nature, or to the Dutch settlers in New Amsterdam, he would look in vain; for, so far as known, all the colonists in what is now the United States were content to depend upon European textbooks to supply the needs of the relatively few schools that they maintained in the seventeenth century.

The earliest mathematical work to appear in the New World, however, antedated Hodder and Greenwood by more than a century and a half. It was published long before the Puritans had any idea of migrating to another continent, and fifty years before Henry Hudson discovered the river that bears his name. Of this work there remain perhaps only four copies, and it is desirable, not alone because of its rarity but because of its importance in the history of education on our continent, that a record of the text should be made generally accessible.

In making the translation the original methods of expression have been followed in many cases in which smoother diction would have suggested greater freedom of rendition. The reason has been, in general, the desire to bring such expressions as " 8 per cent," " 8 per IOO," " one $\cos a$ and $\frac{1}{2}$ a $\cos a$," and "four and $\frac{1}{2}$ " into sharp contrast with the corresponding ones of the present time, and to show the great advance in symbolism and in methods of solution and proof. Such minor errors as were common in a century of careless proofreading have usually been corrected without comment. Aside from this, a certain freedom of translation has been assumed for the evident purpose of aiding the reader to follow the spirit of the text.

The editor wishes to express his indebtedness to Señorita Carolina Marcial Dorado for her scholarly assistance in the translation of the Spanish text. 


\section{CONTENTS}

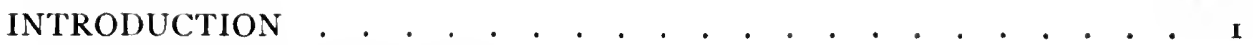

THE MEXICO OF THE PERIOD . . . . . . . . . . . . . . . 3

PRINTING ESTABLISHEI IN MEXICO . • . • . • . . . . . . . . 5

GENERAL DESCRIPTION OF THE BOOK • • • • . • • . . • . . 7

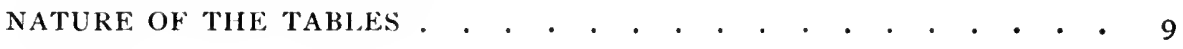

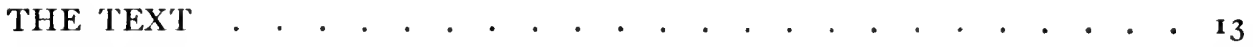

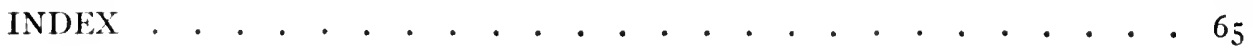




\section{INTRODUCTION}




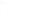




\section{THE MEXICO OF THE PERIOD}

In order to understand the Sumario Compendioso it is necessary to consider briefly the political and social situation in Mexico in the middle of the sixteenth century. Cortés entered the ancient city of Tenochtitlan, later known as Mexico, in the year I 5 19, but its capture and destruction occurred two years later, in 1521 . Thus, in the very year that Luther was attacking certain ancient privileges in the Old World, the representatives of other ancient privileges were attacking and destroying a worthy civilization in the newly discovered continent.

The rebuilding of the city began at once, and the new capital soon entered upon an era of great prosperity, disturbed, however, by the failure of Cortés to show the power as a civil leader that he had shown in his military capacity. The first viceroy of New Spain, which included the present Mexico, was a man of remarkable genius and of prophetic vision, - Don Antonio de Mendoza. $\mathrm{He}$ assumed his office in I 535 , and for fifteen years administered the affairs of the colony with such success as to win for himself the name of "the good viceroy." He founded schools, established a mint, ameliorated the condition of the natives, and encouraged the development of the arts. In his efforts at improving the condition of the people he was ably assisted by Juan de Zumárraga, the first Bishop of Mexico. Among the various activities of these leaders was the arrangement made with the printing establishment of Juan Cromberger of Seville whereby a branch should be set up in the capital of New Spain.

Mendoza became viceroy of Peru in 1550 and died in Lima in 1552 . Upon leaving Mexico he was succeeded by Don Luís de Velasco, a member of an illustrious Castilian family and one who labored faithfully for the betterment of the people intrusted to his charge. One of the first steps taken by him was to found, in $155 \mathrm{I}$, the Real $y$ Pontificia Universidad de la Ciudad de Mexico, and he was at all times interested in the success of the press and in the work of its manager, Juan Pablos, as the name appears in the books of the period. Don Luís died in I 564, sincerely mourned by the people, and was laid to rest in the Monastery of Santo Domingo, in the city in which he had exercised his benevolent authority.

In the same year that Mendoza left Mexico for Peru, Zumárraga passed away, his death being a genuine loss to the State as well as the Church. In the following year Alonso de Montufar* was nominated as his successor and was

* The spelling is substantially as given in the facsimile on page 62 . The first name usually appears as Alphonso or Alfonso. 
consecrated in 1553. For sixteen years he presided with great success over the Church in New Spain, and five years after the death of Don Luís de Velasco he too was buried within the precincts consecrated to the memory of Santo Domingo. It was in his time and with his sanction that the Sumario Compendioso was issued from the press, and well did he deserve the praise accorded to him by a contemporary writer in the words

"Clarissimo, et omnibus animi bonis ornatissimo Sacr. Theolog. Mag. Fr. Alphonso á Montufare, Archipraesuli Mexicano."

Tempora mutantur, nos et mutamur in illis. Such words of praise, expressed in the most sonorous of tongues and in words that seem exaggerated to our ears, belong to the past. In our rapid, unsettled, materialistic life we seem to take pride in our neglect of dignity of eulogy, excusing ourselves by condemning the past as insincere in its praise. Who that reads the story of this early period, however, can say that such descriptions of the characters and accomplishments of those who carried the Cross to the New World were exaggerated, or that they failed to express the genuine sentiments of the people to whose spiritual needs these brothers of the holy orders so conscientiously ministered? 


\section{PRINTING ESTABLISHED IN MEXICO}

The idea of setting up a press in Mexico seems to have been considered as early as 1534, even before Mendoza became viceroy, doubtless at the suggestion of Juan de Zumárraga; but it was not until 1536 that the plan was carried out. Juan Cromberger then sent over as his representative Juan Pablos, a Lombard printer, and so the "casa de Juan Cromberger" was established, prepared to spread the doctrines of the Church to the salvation of the souls of the unbelievers. Cromberger himself never went to Mexico, but his name appears either on the portadas or in the colophons of all the early books. From and after 1545, however, the name is no longer seen, Cromberger having died in 1540.

It was this John Paul who printed the Sumario Compendioso, in 1556 , and in order that the significance of the work may be the better appreciated it is appropriate to mention the following books, known to have been printed by him before that year :

c. 1537 . Escala Espiritual para llegar al cielo, possibly in 1537 , but there is no copy extant. 1539. Breve y más compendiosa doctrina Christiana en lengua Mexicana y Castellana.

1540. Manual de Adultos.

154I. Relacion d'l espätable terremoto.

1543. Doctrina breue.

1544. Tripartito del Christiantssimo y consolatorio doctor Juan Gerson. This contains the earliest woodcut printed in Mexico.

1544. Cöpédio breue ... pcessiones ... por Dionisio Richel.

c. I544. A second edition of the preceding work.

1544. Dotrina xpiana.

1545-1546. Doctrina cristiana.

1546. Doctrina xpiana.

1546. Doctrina cristiana.

1546. Cancionero Spiritual. The first book to bear the name of Juan Pablos as the printer, - "Juã pablos Lõbardo."

1547. Regla christiana breue.

c. 1547. Doctrina cristiana en lengua mexicana.

1548. Doctrina Cristiana.

1548. Ordenã

1548. Doctrina Cristiana en Lengua Huasteca.

1550. Doctrina cristiana.

1553. Doctrina cristiana.

1554. Recognitio, Svmmularum.

1554. Dialecta resolutio cum textu Aristotelis.

1554. Dialogos, by Cervantes (Francisco Salazar).

1555. Vn vocabulario en la lengua Castellana y Mexicana. 
In 1556 five books were published, among them the Sumario Compendioso. It thus appears that not only was this the first book on mathematics, but it was the first textbook of any kind, except for religious instruction, to be published outside of Europe.

In his Bibliografia Mexicana del Siglo XVI, Icazbalceta speaks of a copy in the library of the Convento de la Merced and of one in the Ramírez sale. There is also one in the Biblioteca Nacional at Madrid, from which three folios are missing, and it is this copy that has been used in the preparation of the present work, the missing portion containing parts of tables not included in this edition. There is also a copy in the British Museum.

The author of the Sumario was Juan Diez, a native of the Spanish province of Galicia, a companion of Cortés in the conquest of New Spain, and the editor of the works of Juan de Avila, known as "the apostle of Andalusia," and of the Itinerario of the Spanish fleet to Yucatan in 1518 . He is sometimes confused with Juan Diaz, a contemporary theologian and author. In a letter written to Charles V in $\mathrm{I} 533$ he is mentioned as a "clérigo anciano y honrado," so that he must have been advanced in years when the Sumario appeared. That this was the case is also apparent from a record of the expedition of 1518 in which it is stated that "triximus vn clerigo que dezia joan diaz," doubtless a young and adventurous apostle, full of zeal and desire to make known the gospel in the New World.

The other four books appearing from this press in the year 1556 are as follows :

Costituciones del Arzobispado y Provincia de la muy insigne y muy leal ciudad de Tenuxtitlan Mexico de la Nueva España;

Costitutiones Fratruum Heremitarum Sancti patris nostri Augustini Hiponensis Episcopi et doctoris Ecclesiae;

Speculum Conjugiorum;

Catecismo y Doctrina Cristiana en Idioma Utlateco.

Not again in the sixteenth century did the Mexican printers publish any work on mathematics, except for a brief Instrucción Nautica which appeared in 1587. The press was generally true to its early purpose to issue only books relating to the conversion of the native inhabitants to the way of the Cross. 


\section{GENERAL DESCRIPTION OF THE BOOK}

The Sumario Compendioso consists of one hundred and three folios, generally numbered. After the dedication (folios $\mathrm{i}, v$, and $\mathrm{ij}, r$ ) there is an elaborate set of tables, including those relating to the purchase price of various grades of silver (folio iij, $v$ ), to per cents (folio xlix, $r$ ), to the purchase price of gold (folio lvij, $v$ ), to assays (folio [lxxxj, $r]$ ), and to monetary affairs of various kinds.

The mathematical text (folio xcj, $v$ ) consists of twenty-four pages besides the colophon (folio ciij, $v$ ). Of these pages, eighteen relate chiefly to arithmetic and six to algebra.

The signatures are $a(j, \cdots$, iiij $[\cdots$, viij] $)$, and similarly for $b, \cdots, i, k, 1$, $\mathrm{m}, \mathrm{n}(\mathrm{j}, \cdots$, iiij $[, \cdots$, vij $])$.

Folio $i, r$ consists of the arms as shown in the facsimile, and the title: II Sumario cõpẽdioso delas quẽtas/de plata y oro q̃ en los reynos del Piru son necessarias a los mercaderes : y todo genero de tratantes. Cõ algunas reglas tocantes al Arithmetica. Fecho por Juan Diez freyle.

Folios $\mathrm{i}, v$ and $\mathrm{ij}, r$ contain the dedication to the viceroy, beginning: II Al Illustrissimo Señor Don Luys / de Velasco Visorrey y gouernador d'la nueua España. / \&c. Juan diez freyle: que perpetua felicidad le dessea.

As to himself the author says:

"Por quãto Juã diez freyle estãte pre/sente enesta ciudad de Mexico me a becho relaciõ q̃l cõ ci ã cu y / dado trabajo \& industria a cõpuesto vn libro de quẽtas de plata \&/oro cõ algunas reglas t' uera del ordinario : tocãtes al arismetica: el q̃l es de / mucha vtilidad \& puecho pa en los reynos del Piru a causa d'las muchas / variedades $\tilde{\mathrm{q}}$ enel ay enlas leyes de plata \& oro \& otras cosas $\tilde{\mathrm{q}}$ alla le vsã / lasq̃ les todas estan en el dicho libro muy copiosamẽte puestas."

He therefore undertook the work for the purpose of assisting those who were engaged in the buying of the gold and silver which was already being taken from the mines of Peru and Mexico for the further enriching of the moneyed class and the rulers of Spain. The author felt that he could best serve this purpose by preparing such a set of tables as should relieve these merchants as far as possible from any necessity for computation. For this he had very good precedent, not so much in Spain as in Italy. In 1503 Anton Bartholomeo di Paxi had published in Venice a Tariffa de pexi e mesvre containing numerous tables relating to weight, value, and the like, and intended for the Venetian merchants engaged in foreign trade; in $\mathbf{I} 535$ Giovanni Mariani had published a Tariffa perpetva in the same city and intended for a similar purpose among the merchants of all of Northern 
Italy; and besides these, various other works of a similar nature had already been issued with the intention of relieving merchants from the extensive calculations imposed upon them by the complex systems of measures then in use.

Apparently prompted by the further demand for a brief treatment of arithmetic which should be suited to the needs of apprentices in the counting houses of the New World, the author devotes eighteen pages to the subject of computation and presents it in a manner not unworthy of the European writers of the period.

The most interesting feature of the work, however, is neither the tables nor the arithmetic; it consists of six pages devoted to algebra, chiefly relating to the quadratic equation.

The reason for this interest will be appreciated the more when we consider the state of algebra in Europe in the middle of the sixteenth century. Puzzle problems involving numbers, such as would now be solved by algebra, were known to the Egyptians in the second millennium в.c.; but no treatise upon the theory of equations is known before about A.D. 275, when Diophantus wrote his great work. It is not until the beginning of the ninth century that the word algebra appears in its present sense, having first been used by al-Khowârizmî in a treatise written in Bagdad in the time of the caliphs.

In the Middle Ages there appeared a number of algebraists of ability, notably Leonardo Fibonacci of Pisa, who lived early in the thirteenth century; and little by little these scholars added to the store of material which had already accumulated in the works of the later Greeks and the Orientals.

With the advent of printing from movable types, in the second half of the fifteenth century, there was awakened a new interest in mathematics, and particularly in the field of algebra. The Greek and oriental writers had solved the quadratic equation, but the equations of the third and fourth degrees still awaited solution, and a better symbolism was in urgent demand.

The middle of the sixteenth century saw the solution of the cubic and biquadratic equations by the Italian algebraists, and saw numerous efforts made at devising a convenient symbolism.

It was at this time that Juan Diez wrote. There had already appeared the notable algebra of Cardan (the Ars Magna of 1545), the Germans had published two treatises of merit, and there had appeared in 1514 , from the pen of Gillis Vander Hoecke, a Dutch mathematician, a work of some consequence; but the number of treatises printed before 1556 was small, and these were far from being popular. It is therefore of considerable interest to know that an obscure writer in Mexico should have produced even six pages on the subject at this early period in the development of printed scientific literature. 


\section{NATURE OF THE TABLES}

The general nature of the tables may be seen from the facsimile on page Io. The abbreviations used are as follows:

ps is used for peso and pesos, originally a certain weight of metal, like pound, libra, and lira. The word comes from the Latin pensum, from pendere, "to hang." From the same root we have such words as poise, which also appears in avoirdupois, and such physical terms as pendant and pendulum. The Castilian libra, which found its way into Mexico, was about I.or4 avoirdupois pounds.

$\mathrm{t}$ is used for tomin and tomines. The tomin was the eighth part of a peso, and this was the same as the later real. The peso was therefore a "piece of eight." The tomin was also $\frac{1}{8}$ of a peso of weight, or $\frac{1}{3}$ of a drachm. The name comes from the Arabic tomn, "an eighth part."

mros is used for maravedi and maravedis, a word derived from the name of the Moorish dynasty, Murābitinn, during which the coin was first struck. In these tables 56 maravedis make I tomin, but in tables of a later period the real (tomin) is given as equivalent to 34 maravedis de plata Mexicanos. In some of the tables of Juan Diez the tomin is taken as $56 \frac{1}{4}$ maravedis (fol. lvij), and there are several other slight variations of this kind in the tabular work. The maravedi is also used as a weight, as on page $\mathrm{I} O$.

on is used for onça, our ounce, from the Latin uncia, "a twelfth part," the ounce being the twelfth part of a Roman and early Spanish pound. From the same root we have our inch, the twelfth part of a foot. The uncial script of the Middle Ages received its name from the same source.

gros is used for grano and granos, our grain as a unit of weight, one twelfth of a tomin;- " I2. granos q tien vn tomin."

$\mathrm{U}$ is often used for 1000 . Thus, we have $\mathrm{ijU}$ for 2000 , iij $\mathrm{U}$ for 3000 , and so on. The name for $\mathrm{U}$ is cuento, given in the tables as cueto, a word derived from contar, "to reckon." This use of U was common in Spain in the sixteenth century and has an interesting history. The symbol may be seen in the last two lines of the facsimile on page 10 , where 300 maravedis correspond to $\mathrm{jU}$ pesos, that is, to 1000 pesos. The $U$ in this sense is of uncertain origin. It appears a century earlier as ( $)$ and may possibly have come from one of the several Roman symbols for a thousand. Among the curious variants are $\mathrm{D}$ with the vertical bar duplicated, and a symbol resembling the late Greek character for 900. In the sixteenth century the Portuguese used for the same purpose a symbol, the cifrao, which somewhat resembled our present dollar sign. 


\section{íblatabe, mil.o, deley, fo. iij}

खा1a ärta inedia on fon

II. On

tii. On

iili.oll

. D. 011

Di.ol1

vif.en p̄s t.rlvi.mpro. py f.t.kxkvi\}. po iá.t. rpiö. TE Vi.fKKKDij. i.j.

i.po v.t.rvii)

ii ils t.jkevil.

ij. p̈siiilot.

ij.pspij.t.rpili. ilvl.mícos rlpijumFos rlpiiimros rlik.mín 08 l. Mros i finros I li.miros !(iii). Inf08

f. IIIrosos if.mŕos Iij.mros iiij.míos D. mío8 vi.mŕos ví..nFos bilf mros if.mŕos

\section{iii is}

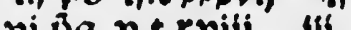
vi p̧s D.t.EDiij. Iij. r. $\bar{p} 8 \mathrm{t}$.

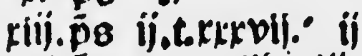
Evi.ps v.t,kbili. lii. kx. $\bar{p} 8$ t. kxiij.pe iu.t.kerpij. if kFpi.ps v.t rpilf. lij. KkF. p8 t. IDij.1117\%os ivilimrios
1. Mifos reriii. p̈s if t.Kervil. if lit.minos le. vi.ps v.t.kpilf, ii). rtr.mFos c. ps $t$. il. in ros creriij ps if.t.xkedif .t). Irik mros rl i.mFos crekpipg v.t.kDiij. iij rlii. Imros ckl. pe.

rliii in ros crliü. Tिs ij.t.krkpil. if riiiijuroz ctlvl.jos v.t.Fpilf. Hi. rlp. $11108 \mathrm{cl}$.

Ixiii) mŕos IFD. 111 TroB LKF. miros

If. mivos

c. 1 III 08 I iij.Jinros

cliti. 58 ij.t. Kruvii if. clpi.pe v.t.teplif.iij. clf. ${ }^{8} 8$

clriif.p8 ii.t. mrpif.if. clepiffe v.t.kwiij, iif. clre. 68 clkeiii 58 ij t. Kkrpij.ij clexpi.p. 8 v.t.tviij,iij. clipki. po

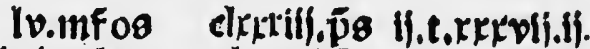
IVj.unros clkrkpj.jpg v.t.fvili, iij. CFe. $\bar{p} 8$ crelij. pos ii.t.txrpli.ii crc.pl.po v.t.rvili.iil. c. $\mathrm{p}_{3}$

ccitipg if't.rexpif.if. CC D). Cer. $\mathrm{p} B$

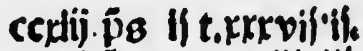
cckp).p 8 v.t.kplif. ii). ecpretij. pis if.t. rekpij. ti. cclcpi.je v.S.fD(i). (ii). cce. $\bar{p}_{8}$ cccrrrii) pis ij.s.rFrnif.ti

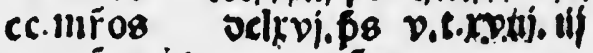
cce, In ros i.v p8 ccccint 08 f.Uceckrriijes ij.r.mept. If a if 
The approximate nature of the tables may be seen from the page here shown in facsimile. In the third line the value of $I$ ounce is given as o pesos 3 tomines 183 maravedis. The half ounce should then be worth half of this, or I tomin $37 \frac{1}{2}$ maravedis, as stated. The quarter ounce should then be worth half this amount, or $46 \frac{7}{8}$ maravedis, whereas it is given in the table as only 46 maravedis. Similar instances of a lack of exactness are found throughout the tables, - a fact that would hardly have been considered significant in the somewhat crude financial transactions of the period.

The Roman numerals are used in all the tables, as was the custom among many bankers in various parts of Europe until the close of the seventeenth century. Where the chief commercial and financial operations consisted in additions and subtractions, these numerals were nearly as convenient for purposes of practical computation as the Hindu-Arabic symbols in use to-day.

The tables extend to "dos mil. cccc. de ley." There is a table of per cents extending to $30 \%$. In this there are such entries as

$$
\text { iij. por . ciento. c. ps iij. p̃s }
$$

that is, $3 \%$ of 100 pesos is 3 pesos.

In general it may be said that the tables give the value of various numbers of ounces of silver in pesos, tomines, and maravedis.

The terms pesos, tomines, maravedis, and varas seem more acceptable in the translated text than any English words, and hence have been used. The more familiar marks, grains, ounces, crowns, and ducats have been given in English.

The tables are no longer of any importance, but as a matter of interest a single page is here shown in facsimile. Only the mathematical text has any historic significance, and it is this that appears in the translation. 



\section{THE TEXT}

WITH TRANSLATION AND NOTES 


\section{iReglasozdinarias.}

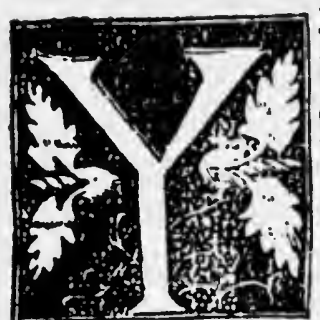

Il que baftantemente tertgo puefto por oonde fin bazer quents fe pueda faber el paloz oc quils quicr varra o tejo de plata 0020 poz difurente ley z péfo que tenga y el valoz oelos quterefis quefe a coltumbzan a oar por qualquicer plata - 0:o bafta treenta pozcíento. a affi mífino cl da loz oe qualefquier pefos oe plata corricnte comi= prados oc elliazado razonando cl znterce de oclos a deente pozci ento juntainente con todo lo nias necefario oela nuetas lifpaña có tas reduciones de pefos oucados y $\mathrm{CO} 2011 \mathrm{~s}$, oe aquí adelante pon= dre algunas reglas oekas necefarias en los reqnos oeliperu junta= inente con algunas quiftiones para curiofos entre las quales van algunas oel urte maroz referuadas al algcbsa: ho quales conlo oe= mas fino fuere talcomo conuiene recebidla voluntad z fea caritatúlamente emendado oe lafalta que tuuiere.

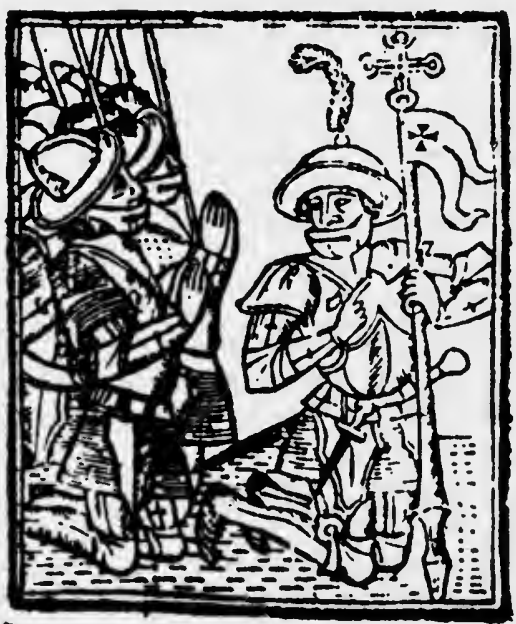
\% 


\section{Common Rules}

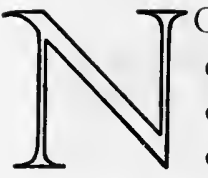

OW that I have sufficiently explained,* without doing the actual computing, how the value can be found of any ingot or bar of silver or gold of whatever standard or weight, and how to find the amount of commission up to thirty per cent which it is customary to give for any gold or silver; and, in the same way, how to ascertain the value of divers weights of silver currency bought as assayed, reckoning the commission from eight to twenty per cent, together with all else that is necessary in regard to the reduction of pesos, ducats, and crowns in New Spain, - from here on, I shall set forth some of the necessary rules which are used in the kingdom of Peru, together with certain problems for those who are interested, among which are certain parts of the arte mayor $\dagger$ pertaining to algebra. If these with the rest do not entirely meet with the approval of the reader, may he accept my good intentions, and, in as kindly a spirit as possible, excuse the mistakes which I may have made.

* In the tables, which make up the greater part of the book.

$\dagger$ The arte mayor was a term commonly used in the sixteenth century for algebra. It appears in the Latin of the period as ars magna and in the Italian as l'arte maggiore. Cardan, for example, called his great work on algebra by the name of Ars Magna, the work appearing at Nürnberg only eleven years before the Sumario Compendioso was published.

The name was occasionally combined with the ancient title, "The Science of Dark Things," used by Ahmes, an Egyptian mathematician of c. 1550 B.C., and with the Arabic title al-jabr wal muqâabalah, used by al-Khowârizmî, c. 820. An illustration of this is seen in the title of Gosselin's treatise, De Arte Magna, seu de occulta parte numerorum quae et Algebra et Almucabala vulgo dicitur, libri $I V$, which appeared in Paris in 1577.

The use of $l$ ' arte maggiore for higher arithmetic (algebra) as distinguished from l' arte minore for elementary arithmetic may have been suggested by the seven arti maggiori and the fourteen arti minori of the merchants of medieval Florence.

The Italians also called the science by the name Regola de la cosa, the reason being that the unknown quantity was called the $\cos a$, as stated on page 51 . Because of this fact the German algebraist Rudolff (1525) called his treatise Die Coss, and English writers of the same century spoke of algebra as the "cossike arte."

The Arabic title given above means "restoration and equation," and hence algebra came also to mean "restoration to health." It is for this reason that, in Don Quixote, they sent for "un algebrista who attended to the luckless Samson." 


\section{TReglas ozdinarias.}

fo.xcii

\section{TEaptulopzimeropozel qualréoag}

entender la regla para bazer de plate cozriente enfazads.

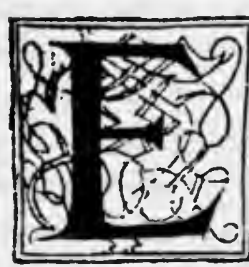

Ftendido tengo que pocas vezes fetaneceflario ba zer quenta que pafie delos vepnte pos ciento que ef ta efcripto: pero oefado efto a partc oare aquíla res. gla para que con faber partír la baga quien quiera:? es que ala cantídad q̃ quieres raber quanto es de en fapado \aina diras adelante oos zeros o cifras como eftas, 00 , \& ocfpucs ajulla con ciento el intereffe qo oas poz lo enfas pado, poz lo qual parte aquelloa q̄ añadifte las 008 cffras, q lo que faliere ala particion feran los pefos enfapados a q̃ re buelue lo ceze riente. Y nota q̃ lo que fobzare enla partteion fon pefos, $\mathrm{z}$ q los bas oe multíplicar p02.8. tomincs que tiene en pefo z lo pzoduzido b̨as ne partir poz el partidoz oe antes q. el aduenimiento fera tomic nes: $₹$ anfi mefmo fi algo fobzare fon tomínes $\mathrm{z}$ bas los oc inultipli car po2. 12.granos qu tiene vn tomín z partír los poz cl inefino pars tidoz: 2 cl aducnimínto fera granos los quales pon con los pes fos z tollines de las particiones oe antes $\backslash$ q aquello fera lo que vale la plata cozriente buelta en enfagada. I fer teauifo que fi eno lo cozrientc ouíere tomínes que poz cada vil tomín pödras en lugar oel.zs 003 cifras.12. $q$ medío z pozque mejozlo entíendas pondre aqui on crillplo.

THeimero Eremplo.

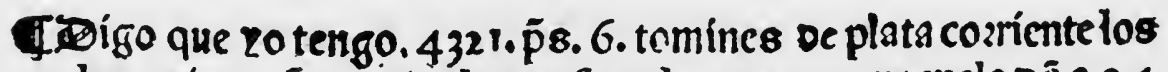
qualcs quiero côpzar ơ platı enfayada o oc ozo que inelo og̃ 9.24 puz cicnto de ynterele para lo qual tengo oicho que ala cătidad co rriente bas oe ainadir ons cifras q fi ouiere tomines poz cada nno

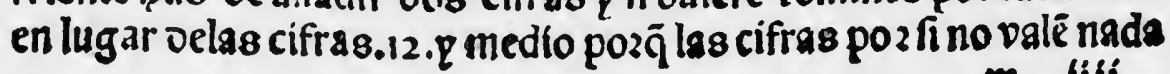

m liij 


\section{Common Rules}

\section{(II Chapter I, in which is explained the rule for finding the value of assayed silver.}

T UNDERSTAND that sometimes it will be necessary to make calculations above the prescribed twenty per cent; but aside from this I shall now give a rule which anyone who knows division can follow, namely : to the amount of

1 money with which you wish to buy the assayed silver annex two zeros or ciphers (Oo); then compute on a basis of a hundred the commission which you give for the assaying, and divide by this the number with the two ciphers annexed ; the result of the division will be the assayed pesos which the currency will buy. It should be noticed that the remainder left from the division represents pesos and must be multiplied by 8 , the number of tomines in a peso; this product must be divided by the same divisor as before, the quotient being the number of tomines. In the same way if there is again a remainder, it represents tomines and must be multiplied by $\mathrm{I} 2$, the number of grains in a tomin, and if we divide this by the same divisor, the quotient will be the number of grains. Now put these with the pesos and tomines and the result will be the value of silver currency in assayed form. Let me also say that if you wish the currency in tomines, put in place of the ciphers 12 and a half for each tomin, and in order that you may better understand I give an example.*

\section{First example}

II Suppose that I have 432I pesos 6 tomines in silver currency with which I wish to buy as much assayed silver or gold as they will give me at 24 per cent commission. $\dagger$ Now to the amount of currency you must annex two ciphers; and if you wish tomines, for each one put in place of the ciphers 12 and a half, because the ciphers themselves are not of any value when considered alone,

* The author here makes an approach to the decimal fraction. A tomin is $\frac{1}{8}$ of a peso, and hence 4321 pesos 6 tomines is equal to 4321 pesos plus $6 \times 0.12 \frac{1}{2}$ pesos. It follows that 4321 pesos 6 tomines is equal to $\left(432,100+6 \times 12 \frac{1}{2}\right)$ hundredths of a peso. If, now, we wish to divide 432 I pesos 6 tomines by 1.24 , we may avoid decimal fractions by dividing 432,175 by 124 . This is what the author does in the illustrative problem which follows.

t The word ynteres (interest) is used by the author to mean any kind of percentage. 


\section{îtegla s ozdinartas.}

7. pucitas alll oelăte firuen de sumiêtar en tal manera dlas oe a tras que al vno hajen valer ciento $r$ anffi poniendo el paloz oe vil tos nin 0008 o qualcs quter tomines firuen poz fi q poz tas 008 cifras poz quanto tienen 008 gracos que fon vnidad $l$ Dezena : $q$ anfli mefmo aumentäal vilo q fea, 100 . I nota que efto no es otra cofa que multiplicar paz100. \ que fe pone afi poz mas bseuedad:pu= es tomando a nueftro e rmplo za vers que lo corriente es, 4321. pefos.6. tomines pezlos quales pon adelantc en'lujar oelas cifias 75.ques fu valoz oelos feis tomínes a ooze z medio cada vno z vie nen a fer. 432175. los quales parte poz ciento p vequte q quatro que fon el valoz oelos. $100, z$ el enterefe $z$ venírte a ala particion. 3485. pefos. z fobsan. 35. los quales baz tomines $\backslash$ que es multi= pli cando los p02.8. 2 fon. 280 . que partidospoz, 124 . vienen.2.to. ¿ fobzá.32.los quales baz granos que es inultipliçando los poz.12 que tiene in tomin 2 fon.384. que partidos poz ciento $q$ vernter quatrote vendran.3. granos que juntos con lo oe mas fon. i485. p8.2.t0.3.granos. 2 efto es enlo que liquidamente fe toz $\mathrm{n}$ an 108. 4321 . pelo8.6.tomines de corriente comprados oe enfazado o de $0: 8$ a. 24 .poz ciento $\mathrm{z}$ fi quieres ver fi es verdad añade les fu pntercile alos .2.4.p02.100.quefon,836.pefos.j, tomines. 0 .g̈ros tevenirte a verilimo.

4321.p̃.6.tomilic8.corriente 000

432175. particion 121

$124 . \quad$ partídos 206

3485.p8:2.to. 3. Tros.enfarado. 06293

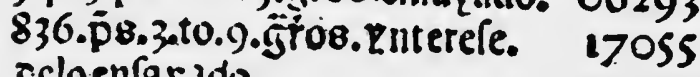
ecloenfariduo.

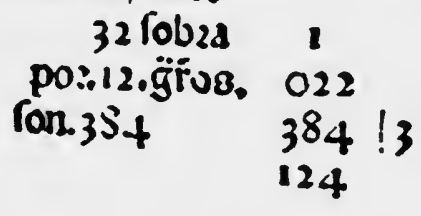

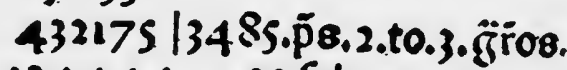

12744435 fobra. 3

1222 po2.8.to. 042

1 Tolr 280 280/2

124 


\section{Common Rules}

but are annexed merely to raise the number in such a way that one becomes a hundred; and substituting the value of as many tomines as you wish, they serve, for themselves and for the two ciphers, to advance the number two places, through units and tens, thus raising one to IOO. Observe also that this is nothing more than multiplying by 100 and is stated in this way for brevity. Now, using our example, we observe that the amount is $432 \mathrm{I}$ pesos 6 tomines. In place of the two ciphers to be affixed, substitute 75 , the value of six tomines, each being twelve and a half hundredths, and the result is 432,175 . Divide this by one hundred and twenty-four, the value of the 100 plus the commission, and the result of the division is 3485 pesos, with a remainder of 35 . This remainder is reduced to tomines by multiplying by 8 , the result being 280 . If we divide this 280 by I24, we have 2 tomines with a remainder of 32 . Multiplying this 32 by 12 , the number of grains in a tomin, we have 384 , which divided by one hundred and twenty-four gives 3 grains.* The entire result now is 3485 pesos 2 tomines 3 grains, the amount of assayed silver or gold purchased with 4321 pesos 6 tomines of currency at 24 per cent. If you wish to prove this to be true, add the commission at 24 per 100, which is 836 pesos 3 tomines 9 grains, and you will see that it checks.

4321 pesos 6 tomines currency 000

432175

dividend

121

I 24

divisor

206

3485 pesos 2 tomines 3 grains assayed

06293

836 pesos 3 tomines 9 grains

commission for assaying

\begin{tabular}{cl}
32 remainder & \multicolumn{1}{l}{} \\
by 12 grains & O22 \\
are 384 & $384 \mid 3$ \\
& 124
\end{tabular}$$
17055
$$$$
432 \text { I } 75 \mid 3485 \text { pesos } 2 \text { tomines } 3 \text { grains } \dagger
$$$$
\text { I } 24444
$$$$
\text { I } 222
$$

35 remainder

by 8 tomines

I I are 280

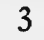

042 $280 \mid 2$

124

* The result should be $3 \frac{3}{3} \mathrm{~T}$, but the fraction is rejected. This shows again how difficult it was to perform such operations to a high degree of precision without the aid of decimal fractions. Indeed, the use of such denominations as pesos, tomines, and maravedis was due solely to the necessity experienced by the ancients for avoiding fractions. For example, 6 tomines is merely a substitute for $\frac{3}{4}$ of a peso, or 0.75 of a peso.

$\dagger$ The method of division here shown is about the last stage of the medieval galley method which had been in use in Europe for a long time. By that method the figures were canceled out as soon as they had served their purpose. Evidently, however, the Mexican press had no canceled figures in their fonts, and hence they do not appear in this text. 


\section{IKcglas ordinarigs,}

fo. גeili).

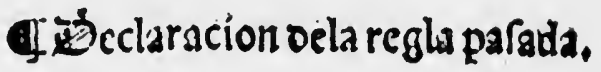

Ghota que la regla paf dda es verifimamaente la regla oe tres y. q affi como elia ic fundia poz plata fe puede fundar poz otras mucbas bías quc bien podria oezir: po tengo.20co.bot1/as oc vino que las

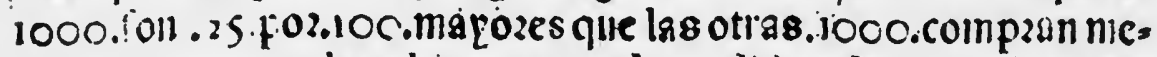

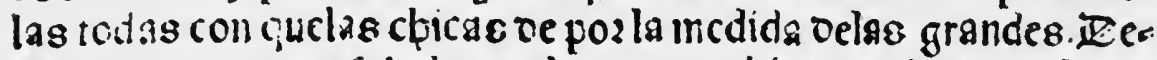
mankin cl: quantag fe bolucran las. 1 coo.chicas medidaspozla mic dida oclas grandes. Âsara elta p las femciantes as de fundarla res

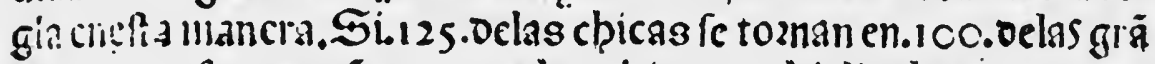
des cia que fe tozmarā.1 1000. Dela e chicas:multipica las. 100C.poz 100. feran.100000.q̃ es lo mífitio como rces que anadir sdclante

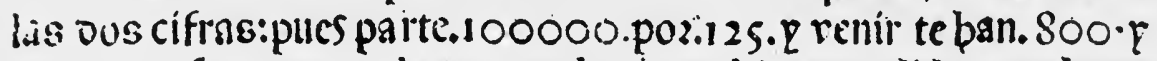
en tant as fe to maran las.1 coo.boti|: \& c chicas medídas foz la me dida oelas grandes:la paneura es que les eches fu intereffe a, 25. poz iCo.? vcitir te ball, 200.colno rcíz figurado

01.1000.botifis grandes.25.poz,100. mas quie 10000 .cpicas.

\begin{tabular}{|c|c|c|}
\hline Fithilitiplicacious & 1000 & 00 \\
\hline Entulip!licado: & 100 & 024 \\
\hline loproditjido & 100000 & 100000.1800 \\
\hline & 125 & 22555 \\
\hline zumiens & 800 & 122 \\
\hline teres & 280 & 1 \\
\hline
\end{tabular}

\section{If bazer oe pefos oucsdos y oe oucados} peíos mue en bzcue.

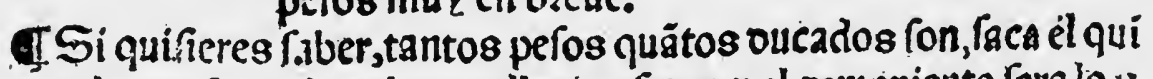
to oclos pefos žr fumalo conellos inefimos a el remaniente fera lo y Defienefabcr. 


\section{Common Rules}

\section{Explanation of the former rule}

(II Observe that the preceding rule is really the Rule of Three,* and in the same way that this applies to problems relating to silver it can be applied to as many other processes or kinds of problems as one may wish. For example, I have 2000 jugs of wine, 1000 are 25 per 100 larger than the other 1000 . Buy them all from me so that you will get the small ones at a price proportional to the price of the large ones. First find how many of the small jugs are equivalent to 1000 of the large jugs. For this and for like problems the rule can be applied in this way: If 125 of the small ones are equal to 100 of the large ones, to how many large ones are the 1000 small ones equal? Multiply the 1000 by 100 and the result, 100,000, is the same as if you had annexed two ciphers; now divide by 125 and the quotient is 800 , the equivalent of 1000 small jugs. To prove this, increase the number 800 by 25 per 100 and the result is 1000 , as you see worked out below.

$\mathbb{1}$ 1000 large jugs, 25 per 100 more than IO0O small ones.

बI Multiplicand $\quad 1000 \quad$ OO

II Multiplier $\quad$ IOO $\quad 024$

dI Product $\quad$ 100000 $\quad 100000 \mid 800$

IIIDivisor $\quad 125 \quad 12555$

IIQuotient $800 \quad 122$

đII Percentage $\ddagger 200 \quad$ I

II A short method of changing pesos into ducats and ducats into pesos

II If you wish to find how many ducats there are in a certain number of pesos, take one fifth of the number of pesos, add it to the number of pesos, and the result is what you wish to find.

* The Rule of Three was the most popular of all the medieval commercial rules. It came to Europe, through the Arabs, from the Hindu arithmeticians. In the Middle Ages it went by such names as the Regula de Tribus, Regula Rerum Trium, Regula Aurea, and Regula Mercatorum.

† The Latin form was 25 per centum, whence 25 por ciento, $25 \mathrm{pc}, 25 \stackrel{\circ}{\circ}, 25 \%$, and $25 \%$.

$\ddagger$ It will be observed that there are two inaccuracies in the original edition, namely, 10000 appears for 1000 , and 280 for 200 , "ynteres." 


\section{î́eglas ozdinarias.}

CErempla:

5445.p̋s el quinto es,89.que fumados juntos montan.534. $z$ tan tos oucados fon los.445. p.

[265.p̄s.el quínto es.53. fumados cólo8.265. fon.318.como vęs

TSi quifieres faber vna cantidad ve oucados quantos pefos fon faca alfermo de los oucados, p. lo que reftare fera lo que bufcas.

C. Eremplo.

G534. oucados el fermo es,89.reftados oe.534.quedan.445.2tä tos peros fon los.534.0ucados.

F318.oucados:el relmo c8.53.reftados oe.318.quedan.264.

IReduzír pefos a maranedis fin multiplicar.

ISl quifieres faber vin ozdei muq bucua para faber vna cätldad De pefos quantos marauedis fon poz muq mas facil p bzeue mane. ra qu inuliplícar: paz los pelos millares p faca el oíezmo, $x$ oelo que reftare la mitad y aquello fera lo que oeffeas faber.

GEreinplo.

T'Toma.456,p̈8.bazlos inillares fort. 45600 c, el oíczmo oclos quales e8. 45600 . (como verze figurado) q̃ rettados ocl p:inccipal quedá, 410400 . la mitad c8.205290.111 r̈s. Q tanto molttan los 456.peros a rajon oe.450.inarauedis el pero.

$$
\begin{aligned}
& \text { 456.p8. fon } 456000 \text {. } \\
& \begin{array}{l}
\text { El oiczmoes } \\
\text { Reftan } \\
\text { Lamitades, }
\end{array} \frac{\frac{456000}{410400 .}}{\frac{405200 . \text { marauedis. }}{205}}
\end{aligned}
$$

GSem ciante ala paffada en ina 20 ? cantidad.

Toma.34568.pefo8. + tollines 2 bazlos nitlarce 2 pozel me dto pefo pon.500.zferan .34568500.el oiezino es. $3456850 . r c=$ Atados oel p:incipal quedan. 314 ti650. la mitad e8.15555825.mara uedis como vere pos la figura. 


\section{Common Rules}

\section{Example}

$\mathbb{L}$ One fifth of 445 pesos is equal to 89 , which added to 445 gives 534 , the number of ducats in 445 pesos.

$\mathbb{L}$ One fifth of 265 pesos is 53 . Adding this to 265 gives 318 , as you see.

III If you wish to find out how many pesos there are in a number of ducats, subtract one sixth of the number of ducats from the number of ducats.

\section{Example}

III One sixth of 534 ducats is equal to 89 , which subtracted from 534 is equal to 445 , and this is the number of pesos in 534 ducats.

$\mathbb{1}$ One sixth of 318 ducats is equal to 53 , which subtracted from 318 gives 265 .

$\mathbb{\mathbb { N }}$ To reduce pesos to maravedis without multiplying

$\mathbb{\mathbb { N }}$ If you wish a good rule for finding the number of maravedis in a certain number of pesos by a much easier and shorter method than that of multiplying, raise the number of pesos to thousands, find one tenth, subtract it from the number of thousands, and then find one half of the remainder; this gives the required number.

\section{Example}

II Raise 456 pesos to thousands and you have 456,000 ; one tenth of this is equal to 45,600 (as you see by the work); this subtracted from the principal leaves 410,400 , the half of which is 205,200 maravedis, and this is the number of maravedis in 456 pesos at the rate of 450 maravedis to a peso.

456 pesos are $\overline{456000 .}$
The tenth is
The remainder
The half is
Th

$\mathbb{1}$ Similar to the above, using larger figures

đI Take 34,568 pesos 4 tomines and raise them to thousands, and for the half peso put 500 , and the result will be $34,568,500$. One tenth of this is $3,456,850$; and this subtracted from the principal leaves $31,111,650$. One half of this is $15,555,825$ maravedis, as you see by the work. 


\section{incislas ozdungrias, foxcciii}

3456 s.p.p.4.to.

IYo eltutengopozm?e. joz êfer bzeuc q ciertaco mo vcras filo vriss.

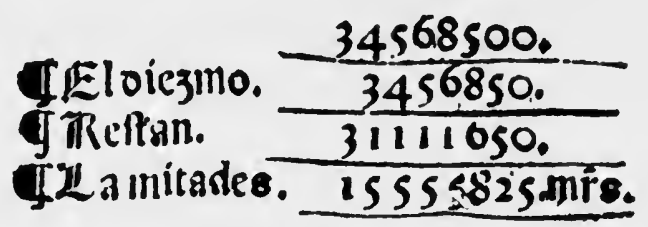

TSi quificrco laber tantos pefos quantas cozonas fon fin bazer. lo poz inarguedis, mnitiplica los pefos poz nueue 2 parte poz fiete, rel aducnimisnto eran cezonas.

25 Ercinplo.

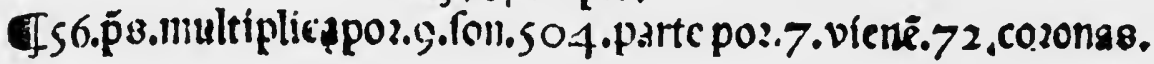

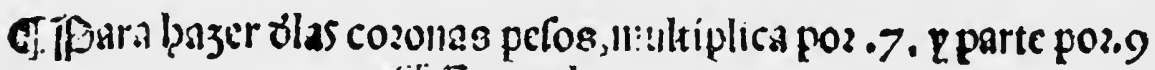
if IExcinplo.

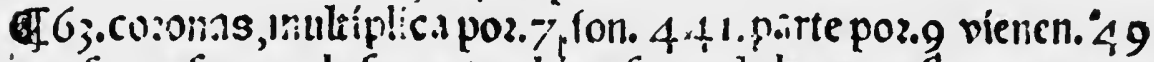
que forl pcfos pozla furna:tamlien fe puicde bajer oefia allancra, \&e 10s.56.pefos añade fus cos fetenes que foil.16. p ereran las.72.0020 nas, la oila olas.63.cozonas rcfta fus dos noucnes que foll. 14 . que dan lov. +9. péfos coino rezr.

Ifijara bajer oe oucados cozona \& y oc cozonas ouesdos, aunque eita puefto poz quenta, multíplica los cuçados poz. 15 . ₹ parte poz

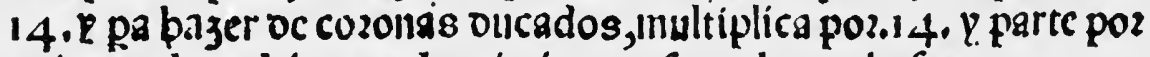
quinze, $x$ los vltíncs aduenimientos ferail lo que bufcas,

TErcinplo.

I42. oucados, multi, lica por..15. fonl.630.parte po2,14, e renírte ban. 45. $q$ tanta8 k020nas fon lo8.42.0ucedos.

TEreinplo.

T60.cozonas, multíplica p02.14. fon.840. parte po:.15. vicnê.56. $\mathrm{q}$ tantos oucados fon las.6 C.c020nas:tain bien lo puedes bazer co mo lo paffado: ree quealos.42.0ucados ajuftes fu catorgauo, que estres: con que fon la8.45.cozonas: 2 afti ní́mo alas . . cocsenas 


\section{Common Rules}

34568 pesos 4 tomines

(II I consider this the shortest and best and surest method, as you will see if you use it.

\author{
34568500. \\ II The tenth 3456850 . \\ III Remainder 31111650. \\ đII The half 15555825. maravedis.
}

II If you wish to find how many crowns there are in a certain number of pesos, without reducing to maravedis, multiply the pesos by nine and divide by seven, and the quotient will be crowns.

\section{बII Example}

II 56 pesos multiplied by 9 is 504 . Divide by 7 and the result is 72 crowns. II To reduce crowns to pesos, multiply by 7 and divide by 9 .

\section{ब1 Example}

II 63 crowns multiplied by 7 is equal to $44 \mathrm{I}$. Divide this by 9 and the result is 49 , which result is pesos. These two rules may be worked out in this way: For the first rule, to 56 pesos add its two sevenths, which is 16 , and the result will be 72 crowns. For the second rule, from 63 crowns subtract its two ninths, which is 14 , and the remainder is 49 pesos as you see.

(II To reduce any number of ducats to crowns, multiply the ducats by 15 and divide by 14 ; and to reduce crowns to ducats multiply by 14 and divide by 15 . The quotients will be the desired numbers.

\section{(II Example}

$\mathbb{1} 42$ ducats multiplied by $\mathrm{I} 5$ is equal to 630 ; divide this by $\mathrm{I} 4$ and the result is 45 , and so many crowns are the 42 ducats.

\section{बII Example}

近 60 crowns multiplied by 14 is equal to 840 ; divide this by 15 and the result is 56 , and so many ducats are the 60 crowns.

Also you may reduce the first of the above sums, involving the 42 ducats, in this way: add to 42 its one fourteenth, which is three, giving 45 crowns. Proceeding in a similar manner with the second, from the 60 crowns, since they are 


\section{iReglasoxdinarías.}

pozque vienen a menos, reftales fu quinzauo que 88,4 . quedä los s6.0ucados.

Tauifo de menosia:

TISl quifieres faber oe inemozid muq facil $p$ beriflumamente vna cantidad oe marauedis quantos pefos ion, oobla los millares \& oef pues añadeles fu oiezmo bafta que no ąd cezenas, 2 éla fuma poz cada pnid.ud to:lld. 50.maraucdie: r pos 4 imejoz lo entiendas nota efte epeiniplo puzque ine pirece te baftara.

\section{TEremplo.}

IToma.120000. Inarauedis,00bla los millares fon.240.el olez=

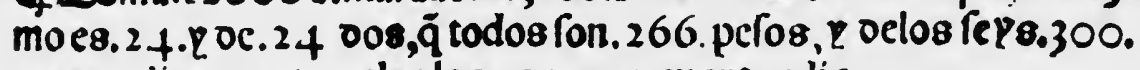
marsucdis, $\mathrm{e}$ tanto palen l08,120000, Imarauedis.

\section{T Julio para raber lo que fe oeue de quinto oe qual quier plata corricnte que fe fuere a quiltar.}

4. Si fuerce a quintar alguna plata cozricinte $q$. quifieres faber poz la plumis o oe cabeç.1 lo que te ban de lleuar be quinto, toma el quar to oelo que fueris a quintar razonando el im arco $a .+. \bar{p} 8.2$ ocfpues toma ono poz.100.oclo mefino y fumalo concllo, p la fuma fera lo quc deues oel quinto $q$ oerecbos oel vno poz ciento: 2 para mas fac tilfacion tupa pondre ona figura.

TiErcinplo.

If Toma.4575. pes हैa vna raka poz ocbaro p. lucgo faca el quarto ea.11 + 3.pelios.6.tominces r. oefpues pon oebdro bno poz ciento o lo que fullte a quintai que fon. 45. pefos.6.tomines poz quanto los 75. que te fobsaron foin tres quartos be, 100. ? afli los tres quar= tos de dil pofo ron.6. tonines:lo qual funis conlos de mas q montaran.1159 pefos a 4 tollinico:p tantc es lo que te pan oe lleuar be :quinto z derécpos como vera figurddo. 


\section{Common Rules}

to be reduced, subtract the fifteenth part, which is 4 , leaving 56 ducats.

\section{ब1. A rule to be memorized}

बII If you wish to memorize an easy and sure way for finding the number of pesos in a number of maravedis, double the number of thousands, then to the result add its tenth, and so on until there are no more tens. Then for every unit in the sum take 50 maravedis. In order that you may better understand this rule, consider the following example which seems to me to be sufficient.

\section{đII Example}

II Take I20,000 maravedis, double the thousands, and the result is 240 ; the tenth of this number is 24 , and the tenth of 24 is two, and the sum total is 266 pesos. In units column there is 6 , and for each of these units take 50 maravedis and the result is 300 maravedis. Thus we have 266 pesos 300 maravedis, which is the value of 120,000 maravedis.

\section{II $A$ rule for finding the tax on any amount of silver currency to be assessed}

III If you are to compute the tax on any amount of silver currency and wish to know how much they will demand, take one fourth of the amount to be assessed, reckoning the mark at 4 pesos; then take one per cent of the original amount, add the one fourth and one per 100, and the sum will be the tax and the one per cent fee demanded. For a better understanding I shall set forth an example.

\section{बII Example}

II Take 4575 pesos, draw a line underneath, below this write one fourth of the number, or I I 43 pesos 6 tomines, and below this write one per cent of what you took to be assessed, or 45 pesos 6 tomines. The 75 which is left over is three fourths of 100 , and the three fourths of a peso is 6 tomines. Add these together and the sum, I I 89 pesos 4 tomines, is what they will demand of your money, including the fee, as you will see in the work below.*

$$
\text { * That is, } 25 \%+1 \%=\frac{1}{4}+1 \frac{1}{100} \text {. }
$$




\section{TReglas ozdinarias.}

fo.tecv.

Tlias oe tener auifo q̃ filo bizieres pozınar cos, que bus de toinar pòz cada marco, $1, p 9, z$ poz cada onça vil, to, 2

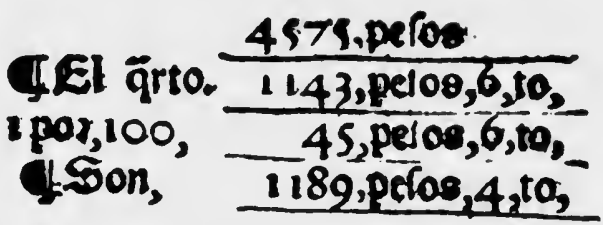
pozcada quarta trce granos, y mas el ono poz ciente comotêgo os cbo, $y$ nota que todo lo del ino poz cicnto es los oerecboe del mar cadoz, , no inas, pozã aunq̃ a el le viene el ärto mas oe oerecbo que aq́fe lc oa fu mageftad lolleua oe incnos: $z$ la caufa es quele paga el vno poz ciento oelo que le ricne oe quinto como tu oclo ą lleuas a quintar o poz mejoz oczír fe lo quinta de balde.

4 IBup mucbas mancras ar oe multiplicar entre las quales ro te go ell a pos la mejoz 2 oc mas verdad a certidumbze lo vno poz no fe lleuar nada o memozía lo otro pozque para la regla de tres no es neceffario mudar las letras para aucr oe multíplicar.

1. Efremplo.

I 19 igo que multipliques,879,p02,758.lo qual pas de.poner enla manera como bes figurado y oar entre la multiplieacion $q$ multíplt cadoz ona ra za como efta. $\backslash$. $₹$ oar oebapo otra rapa coniequt pea Y5.875 $\backslash 978$, . luego cöel 8 , pzímera letra ve mano z3quferdaques: imulniplicadormultíplica todas las oela multíplicacion que fon los oe adelante oela razs pontendo las letras enetta manera, 8 , veses, 9 fon, $7 \%$, el fiete quc es oezena oebaro oel, $8, y$ el, 2, que es onidad va grado adelante que f:ra oebaro oel, $7, x$ fino oufera vnidad aulas 8 poner la oezena en li mefmo lugar oebaro dela letra que tomafte poz inultiplicadoz Y pos la vinidad enel grado adelante vn zero como efte. o. p fino ouiera dejens no auias oe poner nada:pero la ont dad en fu lugar vn gradoadelante oe oo aufa of eftar la vezeria 2 lue

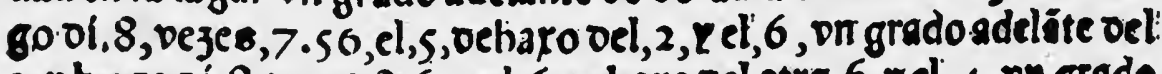
2 , pluego oi. 8, rezes, 8,64, el, 6 , oebaro vel otro, 6 , z eli, 4 , on grado. arelante, que es ocbar.o ocla prímeraletra oc la multiplicectoniago 


\section{Common Rules}

II Let me advise that if you wish to do this by marks of weight, for each mark take I peso; for each ounce, one tomin; for each quarta, three grains, and besides đI The fourth
$\begin{aligned} & \text { I per } 100 \\ & \text { II Makes }\end{aligned} \frac{4575 \text { pesos } 6 \text { tomines }}{\frac{45 \text { pesos } 6 \text { tomines }}{\text { II } 89 \text { pesos } 4 \text { tomines }}}$ the one per cent of which I have spoken. Observe that the entire one per cent is the fee for the weigher or assayer, and no more, because, although there is due him one fourth more as a fee than is given him by his majesty, he receives less than this. The reason is that he pays to his majesty one per cent of that which is due himself of the tax, as you do on what you take to be taxed; or better expressed, it is taxed gratis.

$\mathbb{\mathbb { }}$ There are many ways of multiplying, * among which I consider the following to be best and most accurate. For one reason, no memory work is required; and for another, according to the Rule of Three it is not necessary to move the figures in order to know how to multiply.

\section{Example}

II To multiply 879 by 758 , we must place the figures in order you see set forth, and draw between multiplicand and multiplier a line like this $\backslash$, and then draw underneath them another line, thus : $875 \backslash 978$. Then, using the figure 8 , the first one on the left-hand side, which is the multiplier, multiply all the figures in the multiplicand which are beyond the line in the following manner: 8 times 9 is 72 ; place the 7 , which is tens, under 8 , and the 2 , which is units, under the next figure, which is 7 . If you have no units, you must put the tens in their place under the first figure which you take as the multiplier, and in the place of units you must write a zero, like this: o. If you have no tens, you must not put down anything, but must put the units in the column next to the one in which there would have been tens. Then observe that 8 times the 7 of the multiplicand is 56 , and so we place the 5 under 2 , and place 6 in the next column after 2. Similarly, 8 times 8 is 64 , and we place the 6 under the other 6 and place 4 in the next column under the first figure of the multiplicand.

* The method most commonly used in the sixteenth century was not the one given in the example, but one of the two known by the Italian names gelosia and bericuocolo. 


\section{ineglas ondiftarias.}

maetd el, 8,2 tomo cl, 7, oe oetrite conel qual of, 7 , nezes nueue, $6_{3}$ d, 6, Decbaro oel, s, enta meerims oiden de el, 7 ; 2 e el tree vn grado ade

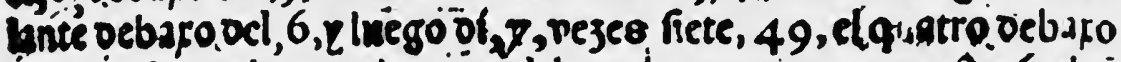
oel, 3, Rel; 9, ocbaro oel, 4 , oe adglante lui:go oi, 7, vese, , 8, 56, elci co oebajo oel nueue r el, 9 , oebafo oel, 7 , fégü dretra dela inultiplicació:pgoris oefacl, $7, x$ to mad, $5, q u c e s$ polt reto multiplicedo 2 con el ăl Q 4,5, , pezer, $9,45, \mathrm{cl}, 4$, eebaro ocl otro, 4 , enla oxden, ol, 5 , que tomafte poz multiplicadoz $p$, cl,

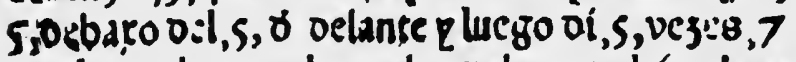
35 fel,3, Debaks oel, 5,2 el,, 5 , oebako del, $6, p$ luce

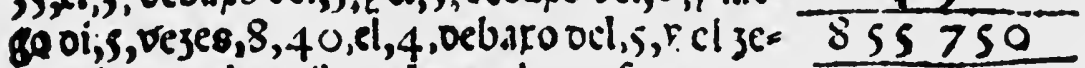
ro oeidatio ocla pottrera letra z lucigu filling.

TiRegla para cobar oe fu magellad po: el quinto.

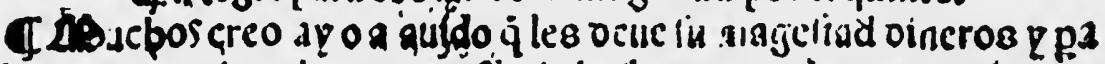
los auer oe cobzar les ce necefiario bulcezr o: 0 o plata poz quiar pa raque poz el quintu lo coluzen los quislez poz 110 raber lo que an 8 ile

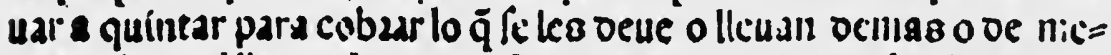
nos delo qual lleu.ndo oc mas lecs es periurzio en que la plata q 0:0 quelleuan leo queita interefice p lleuando oe menos les cos nefcellis = rio boluer otra ves a quinter De que tengo entendido algurios reCi= ben peradumb:e r. para los takes conapuda oe díos dare squi ona regla coino facil z fin ningun perro fepan lo que pã oe llcuar s quin urpara cibsar al jufto lo queles deuc.

\section{IRegla.}

Tfonlo que fe tc deuc pos rumia ala qual añade. 008 zeros como eftes:00.p foulerc tuminice pon poz cada tomin en lugar oelos $3 e$

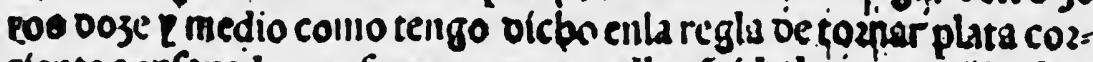
riente a enfazada z oelpucs parte aquella cätidad poz ve znice a feqs Qle que ald particion falicrefera lo que deffeas faber como ald peq. 


\section{Common Rules}

Now leave the 8 and take 7 for the multiplier, thus : 7 times 9 is 63 , so we place the 6 under 5 in the same column as the 7 , and place the 3 in the next column under the 6 . Then 7 times 7 is 49 , and we place the 4 under the 3 , and the 9 under the 4 in the column of the first figure of the multiplicand. Then 7 times 8 is 56 , and we place the 5 under the 9 , and the 6 under the 7 in the column of the second figure of the multiplicand. Now leave the 7 and take 5 , the last figure of the multiplier. Then 5 times 9 is 45 , and we place the 4 under the other 4 in the column of 5 , the multiplier, and put the 5 under the other 5. Then 5 times 7 is 35 , and we place the 3 under the 5 , and the 5 under the 6 . Then 5 times 8 is 40 , and we place the 4 under the 5 , and the zero under the last figure of $\frac{875 \backslash 978}{726460}$ the multiplicand, and then we add.

\section{Rule for collecting what is due from his majesty}

III I believe there are and have been many to whom his majesty owes money. For those who have to collect, it is necessary for them to bring gold or silver to be assessed so that they may collect what is due. These people, because they do not know how much they have to take to be assessed in order to collect what is due them, take too much or too little. Taking too much is hurtful because commission is charged on the extra gold or silver that they take. Taking too little makes it necessary to assess again, from which, I understand, some unpleasantness results. For such as they, with the help of God, I will state here an easy rule, without any error, by which they may know how much to take to be assessed so as to collect justly what is due them.

\section{ब11. Rule}

II Put down the sum that is due you; to it annex two zeros like these: $\infty$. If you would like tomines, put for each tomin twelve and a half in place of the zeros, as I have stated in the rule for converting currency into assayed silver. Divide the sum by twenty-six, and the quotient will be what you wish to know, as you will now see. 


\section{îtuglas ozdinariag.}

fo.gcoj.

IEremplo.

Troigo que te deuan, 1144 ,peros alos qualcs añade 108008 jeros $\mathrm{Y}$ montar $\overline{3}, 114400$, lo qual pte poz $26, \mathrm{~L}$ viene ala particion, $4400 . \bar{p} 5$ que 9,4 ,pefos el marcolon, 1100 , inarcos Q tantos bas o lleuar a qui tar para cobzar lo8,1144, peros la paucua fera que faquesel $\frac{1}{4}$ Y oefpu es vno poz ciento como te tengo of cbo enla fegunda regla ante; delta. canui adcläte pondre algunas paeguntas que aunque no fonn ne. ceflarias para lo que encfterezno fe vfa $\backslash$ los que fon oficionados glia quenta fe bolgaran con ellas pozque sunque no fon futiles parn los qu: algo faben los que lo defiean fa ber con ellas tendran patice pios para inas fubtr.

Itozinerapzegunta.

If Fuia quintar cierto ozo no re lo que pague oel quinto pozq̣ me lo quitaron de ona libranļ̧, pero fe que facsdos quintos a oeres. cbos ine cofto efte $0 z 0$ fin intereffe, 1584 ,pefos:oc mando quan: to es lo que me quitaron enla libzança q que es to que agoza valecefte 0:0. Thegla faca el $\frac{1}{4}$ oe, $1584, e 8,396$, fumslos Cô, 1584 , fon 1980 los qualcs parte poi, 99 , el aduenimiento cs veznte afuft:dosa, 1980 , fon, 2000 , $r$ tanto pale sgora el 020 , fuma, 396, con, 20 fon, $416, x$ tanto re quito rela libzança veriffimo.

đS:gunda pregunta.

IS Semcjante ala paffada fui a quintar rn pedaço oc ozo no fe lo $\bar{q}$ pefaua antes o quintar pero fe que me quitaron oel, 416 , pefos oc oerccbos. 2 emando ques lo que me ba oe quedar. Thegla mulriplica 416 , p02,5, fon, 2 c80, parte los por, 26, vienen, 80 , reftados re, 2080 , quedan, 2000 , oclos quales facs cit es, 400 , rettados 


\section{Common Rules}

đII Example

$\mathbb{I I}$ Suppose that there is due you I I 44 pesos. Annex to this number two zeros, making I 14400 ; divide this number by 26 and the result is 4400 pesos which, at 4 pesos to the mark, make II 100 marks, the amount you ought to take to collect the I I 44 pesos. To prove this, find $\frac{1}{4}$ of 4400 , and then one per cent of 4400 , as I have stated in the second rule preceding this one, and then add.

From now on I shall propose certain questions in which, although not necessary for what is used in this kingdom, those that like arithmetic will delight. Although they are not difficult for those who know something of mathematics, those who desire to know more will find in them the beginnings for further advance.

\section{đI First problem}

$\mathbb{I I}$ I took a certain amount of gold to have taxed. I do not know what tax I paid, because it was paid from a bill of exchange, but I know that, deducting the tax and the fees, this gold cost me without commission I 584 pesos. I want to know how much they took from me in the bill of exchange and what the gold is now worth.

Rule: Take $\frac{1}{4}$ of 1584 , which is 396 ; add this to 1584 and the result is 1980 . Now dividing 1980 by 99 the quotient is 20 , and this added to 1980 gives 2000 , the present value of the gold. Adding 396 to 20 gives 416 , and this is what was taken from the bill of exchange.*

\section{đII Second problem}

II Similar to the above, I went to assess a piece of gold. I do not know what it weighed before being assessed but I know that they took $4 \mathrm{I} 6$ pesos as the fee. I want to know what should be left for me.

Rule: Multiplying 416 by 5 we have 2080 ; dividing this by 26 there results 80 . This subtracted from 2080 gives 2000 , from which find $\frac{1}{5}$, which is 400 ;

* We have $25 \%$ of $1584=396$, tax; $125 \%$ of $1584=1980$, value of gold less $1 \%$. Hence the value is 2000 . Then $2000-1980=20$, fee, and $396+20=416$, total payment. 


\section{TiReglas ozdinarfas.}

oc, $2000, q u e d a n, 1600$, oelos qunir \& fuca vno poz clëto fon 26 , re itados $\delta, 1600$, quedã.1584, Y tale c8 lo qu agoza pale d 020. 200as bzeue ajult 2008 jeros comoeft os, 00 , adeläte $0 e, 416$, fon, 41600 parte p02,26, עienen, 1600 , delor quales faca vno p02,100, viene 16,renta00 de,1600 queda n 1! 84,p02 la fuma:

\section{TReicera piegunta.}

TE compzado olez varas oeterciopelo menos,20,pef08 po2,34, pefos y masuna vara o tereiopelo, 8mádo a como coftola vara.ifie gla fuma los pefos, $20,4,3,4$, fon, $54, q u e$ fera tu partícion refta de las, 10 , varas la vna que oize 2 inas, quedain, 9 , varas pos las qua les pte los,54, vienē,6, p tanto es el precío oe cada vara Pr zueua, 10 varas a, 6,pcfos bazeni,60, pelos menos, 20 , pefos quedan, 40, of ze que coftaron, 34,pefos z mas vna vara quefon, 6 , con que vale losinefim08,40, pefos.

TQuarta pzegunta.

TE comp2ado,12, Daras oelo oícbo menos,30,pefos por,98, p̧s menos quatro daras deinādo a como coltola vara, îpota elta q́ es muq bzcue r verífima fumalos pefos, $30,2,99$, fon, 128 , fumalas varas, $12 \chi, 4$, fon, 16, pos los quales parte, $12 \&$, venír te an, $8, \ell$ tã to es el pzecio de cada vara. Pueua, 12, varas a, $\$$, fon, 96, menos $30, e 8,66$, oije coftaro, 98 , menos, 4 , varas que fon, 32 , pe fos que como vers, quedan los oicbos, 66 .

\section{TQuinta preguinta.}

TE compzado,9,varas delo dicbo poz tanto mas oc, 40 ,pefos, quanto, 13 , varas al merimo pzecio valen menc8 de. 70.0 inädo a co mo dofto la vara. Re gla baz como ella paflada funia los pefos, $40, \mathrm{I}$ 70 fon, 110 , fuma las isaras, $9,1,13$, fon , 22, poz los quales parte los

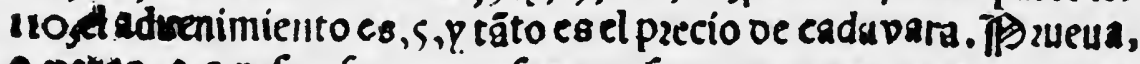
9, baras a, 5, pefos fon, 4 5.pefos que fon, 5 , mas de $40,2,13$, varas a,5,for.65, que fon, s.pefos menos de, 70 , cumo vere 


\section{Common Rules}

this subtracted from 2000 leaves 1600 , of which find one per cent, which is 16 ; and this subtracted from 1600 gives 1584 , the present value of the gold. Briefly, annex two zeros to $4 \mathrm{I} 6$, making $4 \mathrm{I}, 600$; then divide by 26 , giving 1600 . Take one per 100 of this, or 16 , and 1600 minus this gives 1584 , the required sum.*

\section{đI Third problem}

III I bought IO varas of velvet at 20 pesos less than cost, for 34 pesos plus a vara of velvet. How much did it cost a vara?

Rule: Add 20 pesos to 34 pesos, making 54 pesos, which will be your dividend. Subtract one from to varas, leaving 9 . Divide 54 by 9 , giving 6 , the price per vara.

Proof: Io varas at 6 pesos is 60 pesos. This minus 20 pesos is 40 . You paid 34 pesos plus a vara costing 6 pesos, and this gives the result, 40 pesos. $\dagger$

\section{Fourth problem}

III bought 12 varas of velvet at 30 pesos less than cost, for 98 pesos minus 4 varas. How much was the cost per vara? The following is a short method: add the 30 pesos and the 98 pesos, making 128 ; add the number of varas, 12 and 4 , making 16 ; divide 128 by 16 , giving 8 , the price per vara.

Proof: 12 varas at 8 pesos are 96 pesos; this less 30 pesos is 66 pesos. You paid 98 pesos minus 4 varas, or 32 , and this leaves $66 . \ddagger$

\section{đII Fifth problem}

$\mathbb{I I I}$ bought 9 varas of velvet for as much more than 40 pesos as $\mathrm{I} 3$ varas at the same price is less than 70 pesos. How much did a vara cost ?

Rule: Add the pesos, 40 and 70, making IIO. Add the varas, 9 and I 3 , making 22. Dividing $\mathbf{I} 10$ by 22 the quotient is 5 , the price of each vara.

Proof: 9 varas at 5 pesos are 45 pesos, which is 5 more than 40 pesos; and I 3 varas at 5 pesos are 65 , which is 5 pesos less than 70 , as you see. $\$$

\footnotetext{
* The second method amounts to this : $416=1 \%+25 \%$ of amount assessed $=26 \%$ of amount assessed.

$\frac{100}{26} \times 416=1600$, amount assessed.

I $\%$ of $1600=16$, fee.

Therefore $\overline{15^{84}}$ is left after the fee is paid.
}

$$
\begin{aligned}
\dagger \mathrm{1} 0 x-20 & =34+x, \\
x & =6 . \\
\ddagger \mathrm{I} 2 x-30 & =98-4 x, \\
x & =8 . \\
\S 9 x-40 & =70-13 x, \\
x & =5 .
\end{aligned}
$$




\section{Quadrados.}

fo, $\mathrm{kCvii}$.

T.9. bafas poz tanto mas de. 40. . $_{\text {s. }}$ quảto.13. varss alo inílmo. ron menos. oc. $70 . \not 38$.

1.3

\section{Teuiftiones pozlosnumeros ădrados \\ $110 / 5.58$ \\ 22}

$\begin{array}{ll}40 & 9 \\ 70 & 22\end{array}$

11000

ITPara auer oe bajer qualquier pacgunta que te fuere bimandada de numeros quadrados, es neccfiario que fepas queces nuinero äj, drado z pozque fe llama quadrado, z que ca numero cubo rpo:que fellama cubo.

Thumeros quadrados fe llamian ₹ fon aquellos que nacen bla mul tiplicacion o fon produzidos be algun nulliero en otro femejante co mo. 4,9,16, 2c. वेel, 4 , nace oel, 2 , multíplieado pos fi mefino orzien do, 2, veze8, 2, fon, 4,2 el, 9. nace bel, 3, porel mefino configuíente porque, 3 , Dezes, 3 , fon, 9, delos quales numeros los líneales conio el, 2,o el, 3, fon las razzes;

If flumeros cubicos fe llaman y fon aquellos que fon contenidos 8 3,numeros zguales línealcs dela qual inultíplicacion fon oicbos fer p20creados afli como $8,27,64,125,2 c . p 02 q u e, 8$, nace oe, 2, zoef pues enel pzoduzido es a faber, 2 , vezes, $2,4,4,2$, vezes, 4 , fon, 8 , Z,3, Deze8,3,9, 1,33, Deze8,9,27.2C.

\section{9ximera quiftion.}

Ifame on tal numero que bajuftandole, 15, baga numero qas: drado z reftando oel, 4 , fea lo melmo, regla fuma, $15, \mathrm{~L}, 4$, fon, 19, afuftales, 1 , fon, 20, toina la mitad q 98,10 , quadralos en fi pízien: 


\section{Square Numbers}

II 9 varas for as much more than 40 pesos

as I 3 varas at the same price is less than

40

I 3

70 pesos.*

70

I 10

22

$\mathrm{OO}$

I I 0 | 5 pesos

22

\section{Problems relating to square numbers}

III In order to know how to solve any problem that is given to you relating to square numbers it is necessary to know what a square number is and why it is called a square, and also what a cube number is and why it is called a cube.

II A square number is a number that is derived by the multiplication of a number by itself, as is the case with $4,9,16, \& c$. The 4 comes from multiplying 2 by itself, as when we say that 2 times 2 is 4 ; and the 9 is the product of 3 multiplied by itself, because 3 times 3 is 9 . Of such numbers the lineals like the 2 or the 3 are called the roots. $\dagger$

II A cube number is a number that contains the three identical numbers multiplied together, as is the case with $8,27,64,125, \&$ c. ; for 8 is the product of 2 times 2 times 2 ; similarly, 3 times 3 times 3 are 27 , \&c.

\section{बI First problem}

II Give me a number which, increased by $15,1 \mathrm{~s}$ a square number; and decreased by 4 is also a square number. $\ddagger$

Rule for solving: Add $\mathrm{I} 5$ and 4, making 19; then add $\mathrm{r}$ to this result, making 20. Now take the half of this number 20 , which is 10 , and then square this result,

* The work here given shows the cumbersome method used in solving the equation

$$
9 x-40=70-\mathrm{I} 3 x .
$$

f In this work the word root, taken by itself, signifies square root.

$\ddagger$ The rule depends on the fact that $\left(\frac{a+b+1}{2}\right)^{2}-a-b$ (or $\left.+a\right)$ is a square. 


\section{Qufftiones.pozlosnumeros.}

do, 10, veje8,10, fon, 100, oclos quales refta lo8, 15, que fe ari oc ain itar quedan, 35,2 eftc es el numero oemandado, oc ét qual fi reftes

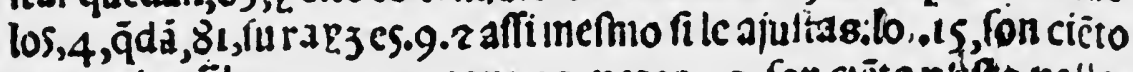
rakj oelos äles e8,10, pozque, $10, v e z c 8,10$, fon clëto \& ifto palla.

\section{FFegunda quiftion.}

Fome on numero que ajuftandole, 8, fca quadrado 2 reftando 81 8.qucde quadrado, toma medíc oe ocbo $c 8,4$, quadrale 28,16 , , 14 ftale, $1, \mathrm{CB}, 17,2$ efte es el numero oemandando, at qual ft ajuits,$\$$, baze, 25, que fu razz $388,5,2$ fil le reft 28,8 , quedan, 9 , que futals $\mathrm{eS}, 3$ poique, 3, vezer, 3, lon nueue como rezs.

GE En mazoz cantidad, oame on numero que ajuftädóle; 20 ; fea nu meto quadrado $q$ reftando vel, 20, quede quadrado, toma initad de $20, c 8,10$, quadra 28,100 , qjufta pno bnze, 101 , tefte esel vn nume

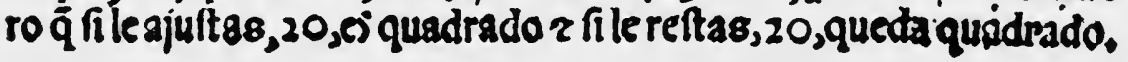

\section{Trouffion tercera.}

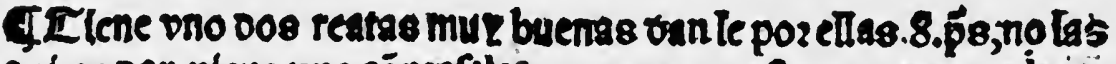
quicre oar, plene vno cóprarelas por vara o enefta manera quele va pos cada vara oc cada vna tantos tomines quantas baras turrére

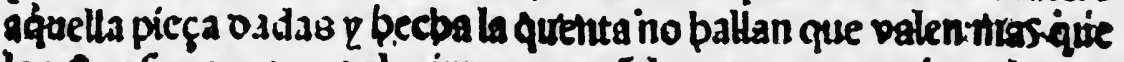
108.8. péos que ouua el paimero,penrädo que raras tenfa cada una poz fi para la qual i egla es firchetter que bufques oos numeros qua drados tales, que juntos en pnono fean mas que pno quiero ofjír. bagan numero quadrado los qhales nameros fon, 3,24 , que murf-

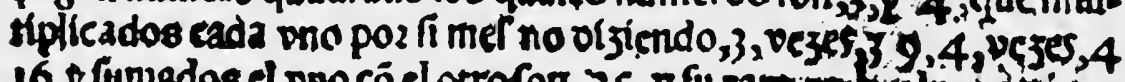
$16, p$ fumados el ono có el otrofor, 25,7 fu rang e-s, iv luegd di po? regla oc, , fi cinço rakz oe, 25 , fon venidos oc,8, que esel palo 2 Des 


\section{Questions relating to numbers}

thus : 10 times 10 is 100 . From this subtract 15 , and we have 85 , and this is the number required, that is, the one from which if you subtract 4 you have $8 \mathrm{I}$, the root of which is 9. The same thing happens if you add the 15 , the result being a hundred, the root of which is IO; for IO times IO is IOO, which checks.

\section{Second problem}

II Required a number which increased by 8 is a square, and decreased by 8 is also a square. Take half of eight, which is 4 ; square it, making 16 ; add $\mathrm{I}$, making $\mathrm{I} 7$, and this is the number which increased by 8 is 25 , the root of which is 5 ; and which decreased by 8 is 9 , the root of which is 3 ; for 3 times 3 is 9 , as you see.* बII Using larger numbers, required a number which increased by 20 is a square number, and decreased by 20 is also a square number. Take half of 20 , namely IO; square it, making IOO; add one, making IOI, and this is a number which increased by 20 is a square, and decreased by 20 is also a square.

\section{Third problem}

II A man has two very good ropes for which he can get 8 pesos, but he refuses the offer. Someone offers to buy them by the vara in such a way that for every vara in each rope he gets as many tomines as there are varas in that rope. When the computation is made, they find that the money is no more than the 8 pesos which the first one offered. How many varas are there in each rope?

To solve this it is necessary to find two numbers whose squares added together make a number which is no greater than that of the one given. These numbers are 3 and 4. Multiply each number by itself and we have 3 times 3 which is 9 , and 4 times 4 which is 16 ; and these added together are 25 , and the root of this is 5 . Then by the Rule of Three, as five, the square root of 25 , is to 8 , the value

* This depends on the fact that

and

$$
\begin{aligned}
& \frac{x^{2}}{4}+1+x=\left(\frac{x+2}{2}\right)^{2}, \text { a square, } \\
& \frac{x^{2}}{4}+1-x=\left(\frac{x-2}{2}\right)^{2}, \text { also a square, }
\end{aligned}
$$

the rule simply giving the expression $\frac{x^{2}}{4}+\mathrm{I}$. 


\section{Quladrados, fo. excuiii.}

lo qfe vendio ve ado vendran, $3,2,4$, que fueron los numeros balla dos multiplica, 8,po2,3, fon, 24, pultte por cuico vienen quatro ? $\frac{4}{3} \mathrm{x}$ eltas fon las parna dela pna, lucgo oi, 8 , veze 8,4 , fon 32 , par te poi, 5 , bienell, $6,-\frac{2}{5}$ Z eftas fon las pard a dela otra que fumadas enittamibas ticnen, 11 , varas $r$ vn quinto r vendidas cada pnapor fi oảdo poz cada vara oe cada.l tantos tomines quêtas varas tiene

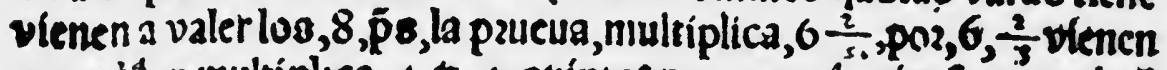

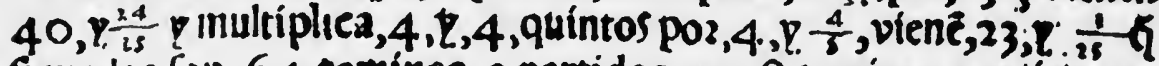
fumados fonl, 64, tomines r partidos pos, s, fonines que tictie von peroforl, 8,pefoo,

\section{Ieuiftion quarta.}

ISitc fuctie pedida wha qufnton en tal manera que te ofreffen,oa me on nuincro quadrado p tal que quirand o oel vina cantidad cier ta qucde quadrado z ajuftandó ie la lea quadrado, para auer de abfolucr vna tal guiftion es heceffario que repas que cola ce numero congruo \& que cofa esinumero congruente.

T. numero cỏgruo fe llama q es on talnumero ques abto a oar que cébir otro numero el qual fe llama congruente en tal manera que ố dole a reçibiendole fiempxe fta quadrado, \& para quuc nicjoz r imas claramẽte lo entiendtes pondre aqui baro los ntimeros congruos y coingruentce que ine parecétéran neceflarios, $q$ afit meémo pödre vn exeinplo,poz cl ăl $i$ bien le netas podras oeclarar todas lis quif

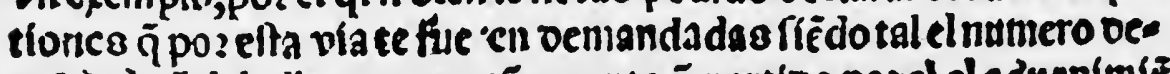
imàdado q̃ le balle numer.o cögruente à partioo pozcl el aduenimié to fea numcro quadrado, po2ȳ no lo ficndo sqotrofecreto, cl qual oefo poznofer prolíto. 


\section{Square Numbers}

at which it was sold, so we have 3 and 4 to the numbers to be found. Multiply 8 by 3 and we have 24 ; divide by five and we have four and $\frac{4}{5}$, and this is the number of varas in one piece. Then 8 times 4 is 32 ; divide by 5 and we have $6, \frac{2}{5}$, and this is the number of varas in the other piece. These added together give I I varas and a fifth. If we pay for each vara of each rope as many tomines as there are varas, the value comes to 8 pesos.

Proof: Multiply $6 \frac{2}{5}$ by $6 \frac{2}{5}$ and we have 40 and $\frac{24}{2}$. Multiply 4 and 4 fifths by 4 and $\frac{4}{5}$ and we have 23 and $\frac{1}{25}$, which added together gives 64 tomines. This divided by 8 , the tomines in a peso, gives 8 pesos.*

\section{$\mathbb{1}$ Fourth problem}

II Suppose that you were given this problem: Find a square number such that if we take from it a certain number, there remains a square; and if we add to it the same number it is also a square. In order to solve such a problem it is necessary to know the nature of a congruous number and of a congruent number.

II A congruous number is such a square number that, subtracting from or adding to it another number, called a congruent number, it will still be a square. So that you may better and more clearly understand I set forth below the congruous and congruent numbers which I think necessary, and I also give an example by which, through careful examination, you will be able to solve all the problems of this kind that may be proposed. The number required must be such that when the congruent is divided by it the quotient will be a square; if it is not, there is another secret way, but this I will not give lest I be too prolix. $\dagger$

$*$ We have $x^{2}+y^{2}=8^{2}$. If we take $v=3$ and $w=4$, we have $v^{2}+w^{2}=5^{2}$. Hence the author assumes that $8: 5=x: 3$, and that $8: 5=y: 4$.

† This congruent number is what Leonardo Fibonacci (1 225) called a congruum, a number of the form $4 x y(x+y)(x-y)$. He gives the problem: "To find a number which, being added to or subtracted from a square number, leaves a square number," and uses the identities

$$
\begin{aligned}
& \left(x^{2}+y^{2}\right)^{2}-4 x y\left(x^{2}-y^{2}\right)=\left(y^{2}+2 x y-x^{2}\right)^{2}, \\
& \left(x^{2}+y^{2}\right)^{2}+4 x y\left(x^{2}-y^{2}\right)=\left(x^{2}+2 x y-y^{2}\right)^{2} .
\end{aligned}
$$




\section{Quiftionespoz los numerns.}

IRọgruos. ILúgruentes.

TEreinplo.

25. Re.zoa. IOn.TRe 20. 169. TRe.p 0.8. 225. TRe. 20 o. 289. TRe.l? $0 a_{+}$ 400.iRe. 09 .

625. Re.pod. 676.îne.toa. 841. RRe.Y Oa. 900. Re.loa. is 6. The.je oa. 1225 . TRe.rog. 1212. Me.EDa. 1681,iRe.p da. 2025. IRe.Yoa. 2500. Re.p 0a.1344 2602. ilic.p od. 27.04. Re.pod, 2SOg. Mic.roa. 3025. RR. POd. 3364. îRe.YOA. 3600 . Tie.r od. 3221.TRe. Da. 4225.île.y 0.1.
24. Tha me on numerogdradotal 96. que ajuftãdole, 6, bags muquero $9=$ 220. dildcia r reftando oel 6 , quede nu= 216. mero quadrado, paralo qual bas 240. De bufcar vn tal numefo congrué 384. te que particindole poz,6, Déga uu $336 \backslash 2,600$. mero quadrado cl qual coino a fue 480. ra vers $\mathrm{cl}$ pillcro es,24, pues par 84c. te,24,poz,6, vierse, 4, que es qua 864. drado (qui raz; cs oos) e luego to 960. ma cl numero congruo quadrado 1176. correfpódiente ocfte numero con 1080. gruente que e8,25, partale pozlos 720. 4, que cs cl aducnimiento oe el 1944. mero vienen, $6, \frac{1}{4}$ q aquefte es 2400. el numero ocmădădo que file aju 2160. ftas fers baje, $12,-\frac{1}{4}$ que es nus 1920. mero quadrado z fu rayzes, $3, \frac{1}{2}$ 2520. Q fi reftas oel, 6 , queda $\frac{1}{4}$ elúu 2905. razzes $\frac{1}{2}$ pozque media pez me 3360. dia es $\frac{1}{4}$ R el inefino es quadra= 3456. do quefurayzes dos q medio. 1320. 2026.
Yyta in alijo. 


\section{Questions Relating to Numbers}

\section{$\mathbb{I}$ Congruous $\mathbb{I}$ Congruents}

100

$$
225
$$

289

400

625

676

$84 \mathrm{I}$

900

I 156

1225

1212

I 68 I

2025

2500

2602

2704

2809

3025

3364

3600

3221

4225
24

96

I 20

216

240

384

$336 \backslash \& 600$

480

840

864

960

1176

1080

720

1944

I 3442400

2160

1920

2520

2905

3360

3456

I 320

2026

\section{Example}

II Find a square number which being increased by 6 will still be a square, and which being decreased by 6 will also be a square. To solve, you must find a congruent number which being divided by 6 the quotient will be a square. The first number, as you see, is 24 ; this divided by 6 gives 4 , which is a square (and its root is two). Now take the congruous number corresponding to 24 , which is 25 . Divide it by 4 , which is the quotient of the first one, 24 , divided by 6 , and we have $6, \frac{1}{4}$, and this is the required number. Add 6 to it and you have $12, \frac{1}{4}$, which is a square number, the root being $3, \frac{1}{2}$. If you subtract 6 you have $\frac{1}{4}$ and the root is $\frac{1}{2}$, since a half times a half is $\frac{1}{4}$ and the same number, $6 \frac{1}{4}$, is a square of which the root is two and a half.

And so with others.*

* In the list read I 521 for 1212,2601 for 2602,3721 for 3221,2925 for 2905 , and 2016 for 2026 . In the problem, since

we have

$$
\begin{aligned}
& 25 \pm 24=x^{2}, \\
& \frac{25}{4} \pm \frac{24}{4}=\frac{x^{2}}{4}=y^{2} .
\end{aligned}
$$




\section{Quadrados. fo.xcix. \\ T.Quiftion quinta.}

ISi quifieres ballar o tc fuere teinshdado que bufques tres nu. meros quadrados o mas q teles que juntos en vno bagati numero quadrado:toma el puímer numero quadrado zinparcs, 9, ol qual \& ta bno quedan, 8, toma la mitad, quadra fon, 16 , r efto is el le gundo afuta, $9, x, 16$, fon, 25 , quitu bno quedan, 24 , tomala mits d e8,12,

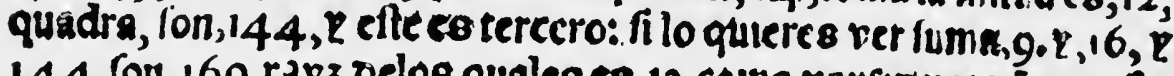

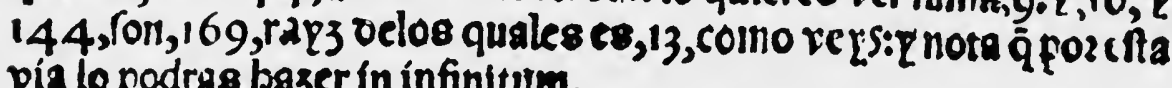
via to podras bazer in infinitum.

\section{F Sefta quiftion.}

If igo que me oes pn tal numero quadrado que quitandele oaju fandole fus tres rapzes bagan nitinero quadradc. Regla ten a n.ié tes sun numero congriente qaun al numero fu zo congruc quedras do correfpondiente $\&$ el tal inmeto congruente parte k por tairsis

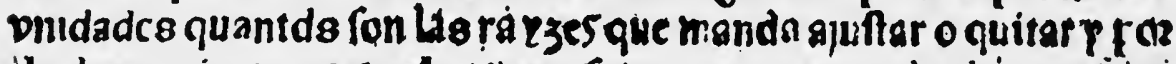
dladuenimicnto parte el rutriero fu fo cel grue quedreco con cificn

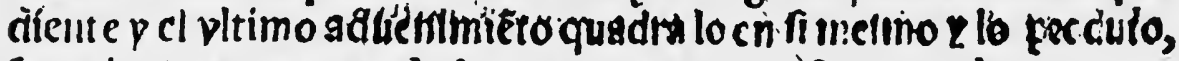
rerg el numer o delnandado como rerso poz ifte crenipls.

\section{TExemplo.}

(1) Toma,24,pzimernumcro congrucntc parte le ró2,3, cille fồtas rarzc8 ocillandadas viene, 8 pozlos quslio frine.25 cile es fu có. gruv quadrado costefpondícnte vicurei. $3, y ; \frac{1}{8}$ lo qual quidra, enll mefino lo pioduto $(8,9, p$. ajuftădole o quítrandolc ius, 3 , rayjes fera quadrado como reqe as juftale $9,2, \frac{24}{64}$ que fon lae trce rar 368 inonta, $19 \%, \frac{9}{04}$. aire es ritime ro quadrado p fu raYzes, $4 Y$ - e file quítas fus, 3 , rayjes que dan si. que es mnnero quadrıdo v fu rap 3 es.5.0 cbabos.

G. Septina quiftion.

Entota elta, 2, vezes, 2, fon $, 4,2,3$ rezcs, 3 fon, 9 , fun ados funtos bazen, 13 , pnes oame otros. 2 . numeros que ni fe an, $2, n i, 3, z$ q̃ quadrados en fr mefinos q lo pzoduto fumadojüto fcälos mefmos, 1 . 


\section{Square Numbers}

\section{$\mathbb{1}$ Fifth problem}

II If you wish to find three or more square numbers which added together make a square, take the first odd square number 9 ; subtract one, which gives 8 ; take the half, its square being 16 , and this is the second number. The sum of 9 and I6 is 25 ; subtract one and we have 24 ; the half of 24 is 12 ; the square of 12 is 144 , and this is the third number. If you wish a proof, the sum of 9 and I 6 and I 44 is I69, of which the root is I 3 , as you see. In this way, you can solve any number of problems.*

\section{बII Sixth problem}

IIFind such a square number that if you subtract from it or add to it thrice its root, you have a square number. Keep in mind some congruent number and its corresponding square congruous number. Divide the congruent number by the number by which you are to multiply its roots when you add or subtract them. Divide this quotient into the corresponding congruous square number and square the quotient. The result will be the required number, as you will see by the following example.

\section{बII Example}

II Take 24, the first congruent number. Divide it by 3 , the number by which you are to multiply the roots, and the quotient is 8 . Divide this 8 into 25 , the corresponding square congruous number, and the quotient is 3 and $\frac{1}{8}$. The square of this is 9 and $\frac{49}{64}$, the required number which, added to or subtracted from thrice its root, will be a square as you see. Add 9 and $\frac{24}{6}$, which is thrice the root, and you have 19 and $\frac{9}{64}$, which is a square whose root is 4 and $\frac{3}{8}$. If you subtract thrice the root, you have $\frac{25}{6}$, a square number whose root is 5 eighths. $\dagger$

\section{đII Seventh problem}

II Observe this : 2 times 2 is 4 , and 3 times 3 is 9 ; these numbers added together make I3. Now find two other numbers, neither 2 nor 3, which squared in the same way and added together will give the same result 13 .

* Take as the first odd number $2 n+1$. Following the directions, the first square is $4 n^{2}+4 n+1$, the second is $4 n^{4}+8 n^{3}+4 n^{2}$, and the third is the square of $2 n^{4}+4 n^{3}+4 n^{2}+2 n$.

t Since

we have, multiplying by $\frac{25}{6}$,
$25-24=\mathrm{I}$,

$9 \frac{49}{4}-9 \frac{3}{8}=\frac{25}{6}$, a square, and similarly for $25+24=49$. 


\section{Quiftiones:pozlosnumezes.}

IRegla.

GHules. 2. numeros. quadrades que bagan numero quadrado que tenga rais oicreta los pzimeros fon. 3.y. 4. que fus quadrados fon 9.q.1 6q juntos azen.25.q̃ ce quadrudoz fu razzes.9. Thues nots que tíence. S. numeros, quefon. 2.2.3. Dimeros.p. $3 \cdot 2 \cdot 4$. q́fonlos pzopueltos q. 5 .que es fu rar 3 ion los como bcis figura da. 2 luagomultiplica en cruz oiziendo.3. vezc8.3. fon.9. 2. "ve= 3e8.4. Fon.3. puilus ala inalio oerccha el pno debapo del otro \& lue go bucluc a dez il pezarriba, 2. rezes. 3. fon.6. poz abafo.3.vczc8.

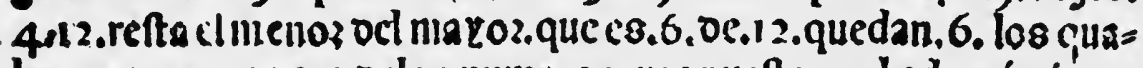
les parte p02.5 razz delos numeros pzic pueftos : cl aducnimiento

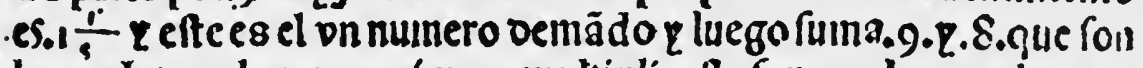
lo produto oclos que pitmero inultiplícalte fon.17. los quales p.Ir

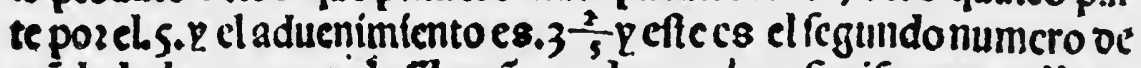
inådado, la paucus oelo q̈lce qै quadres. $1 \frac{1}{5} \mathrm{en}$ fimifmo es.1 $\frac{12}{2} \% .3$ $\frac{z}{s} \mathrm{en}$ fi mefinva fon 1 . $\frac{44}{28}$ que fumados juilios como verg ton los mé́mos,13.
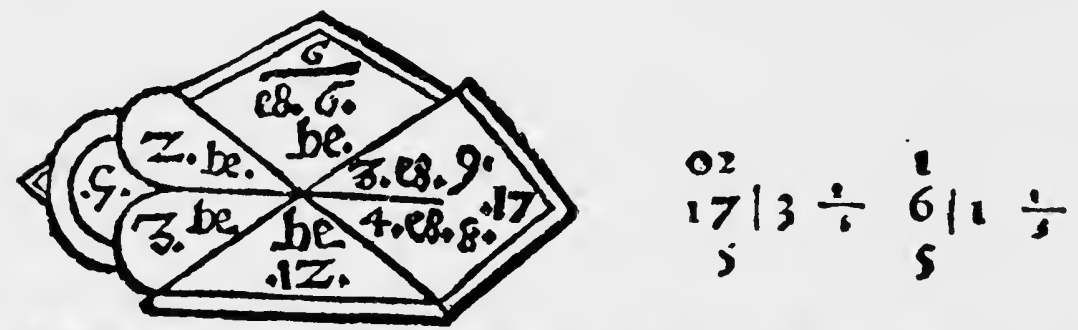

TEs pho que tiene cinco pefas con lasquales puede pplat vefde vn tomin pafta quínce pefos 2 mas, iBeinando que es lo que pefa cada una Pozternario. L a primera, 1, to. IL a fegunada, 3, to. L 2 a

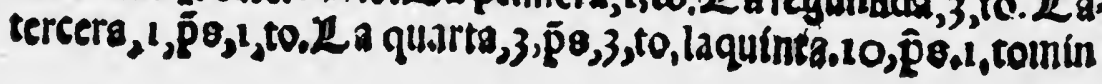




\title{
Questions Relating to Numbers
}

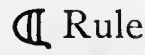

đII Find 2 numbers the sum of the squares of which will make a square number which has an integral root. The first numbers are 3 and 4 , for their squares are 9 and 16 , and these added together make 25 , the root of which is 5 . Observe that you have 5 numbers; the first are 2 and 3 ; the next are 3 and 4 , the proposed numbers; and there is also 5, which is their root. Place these numbers as you see in the figure below. Then use cross multiplication, saying " 3 times 3 is 9 , and 2 times 4 is 8 ." Place these numbers at the right-hand side, one under the other. Then multiply again at the top, 2 times 3 is 6 ; and underneath, 3 times 4 is I2. Now subtract the less from the greater, that is, 6 from 12 , and there remains 6 . Divide this by 5 , the root of the assumed numbers, and the quotient is $1 \frac{1}{5}$, one of the numbers required. Now add 8 and 9 , the products of the first multiplication, and the sum is 17 . Divide this by 5 and the quotient is $3 \frac{2}{5}$, and this is the second required number.

Proof: The square of $I \frac{1}{5}$ is $I \frac{1}{2} \frac{1}{5}$; the square of $3 \frac{2}{5}$ is $I 1 \frac{1}{2} \frac{4}{5}$; and these added together, as you see, make $13 .^{*}$

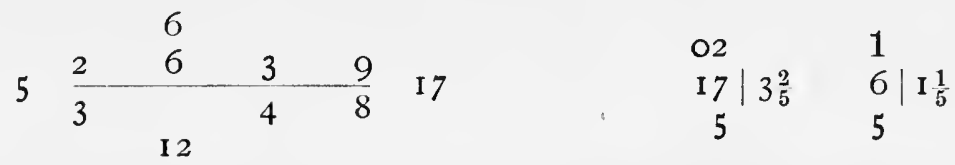

II A man has five weights with which he can weigh from I tomin to fifteen or more pesos. What is the weight of each? The first, I tomin; the second, 3 tomines; the third, I peso I tomin; the fourth, 3 pesos 3 tomines; the fifth, Io pesos I tomin. $\dagger$

* The equation $u^{2}+v^{2}=13$ is indeterminate. It is given by Diophantus (II, 9), a late Greek algebraist of $c$. A. D. 275. In Sir Thomas Little Heath's edition of Diophantus, second edition, page 145, Euler's general solution is given as well as the special solution leading to Diophantus's results. In the latter solution $(x+2)^{2}+(2 x-3)^{2}=13$, whence $x=\frac{8}{5}$ and the two numbers are $\frac{18}{5}$ and $\frac{1}{5}$. This solution is rather more simple than the one in the text.

† This is the well-known Problem of the Weights. Expressed in tomines the weights are $\mathrm{I}, 3,9,27,8 \mathrm{r}$, a geometric progression. This solution requires that the weights be placed on either or both pans of the scales. It is evidently inserted to fill the page, having no close connection with the problems which immediately precede or follow. 


\section{Quadrudos.}

fo.c.

\section{TOctaua quiftion.}

T3. Dezes, 3, fon $9,15,4$, reze8, 4, fon, 16 , fumados ö, 25,que es nu - licro quadrado e fu ra $\mathrm{r} 3 \mathrm{c8}, 5,0 \mathrm{~d}$ me otros,008. numeros, qu ni fea $3, n i, 4, z$ quc quadrados é fi inérmos \& lo produzido fumado fea, 25

TRegla.

TBurca, 2, numeros que juntos los quadrados en vno bagan nu mero quadrado que tenga rayz offcreta:toma, $5, x$ ooze que fus qua drados fon, $25, x, 144$, que fon, 169 , rayz oclos quales c8, 13,pucs nota que enla paflada a efla femcjante tuuilte, 5 , numeros p aquit tie ne8, 4 , la caufa es que, $3,2,4$, pímcros numeros tíenci raq3 bifcre th que c8,5,el qual c8 Ci vno velo8, 4 , y. firue poz cl, 3, $2 \mathrm{cl}, 4$, De qui é es ralz z los otros fó, 5. Z.12, numeros ballados o pzofupucftos Y fu ray 3 que $e 8,13$, loa quales pon enla inanera quever 8 figurado l. con cl, s, ray3, De ,3,2.4, primetos numeros mul.el, S.Y d, 12 , nim.e ros picpucftos diziendo, 5 , vezes, 5 , fon $, 25,2,5$, vezes doze fon, 60 parte entramos produtos po2, 13 , que es la ray 3 oelos nuinieres p2o pucftos q el adueriimlento feran los numeros que burcas:parte, 25 , po2,13, víencn, $1 \frac{12}{11}$ que es el vno parte, 60, p02,13 viene.4, $\frac{8}{13}$ que cs cl otro los quales fi los multíplicas cada ono poz fi mefmo p. lo produzído funnos feran lo8,13, que ocillardas colno reps niul. cn fi. $1 \frac{12}{11} .88 .3$. 113. multuplica en $f, 4, \frac{8}{13}$ c8.21. $\frac{11}{860}$ fuma los $\&$ fon.25.como repe poila figura.
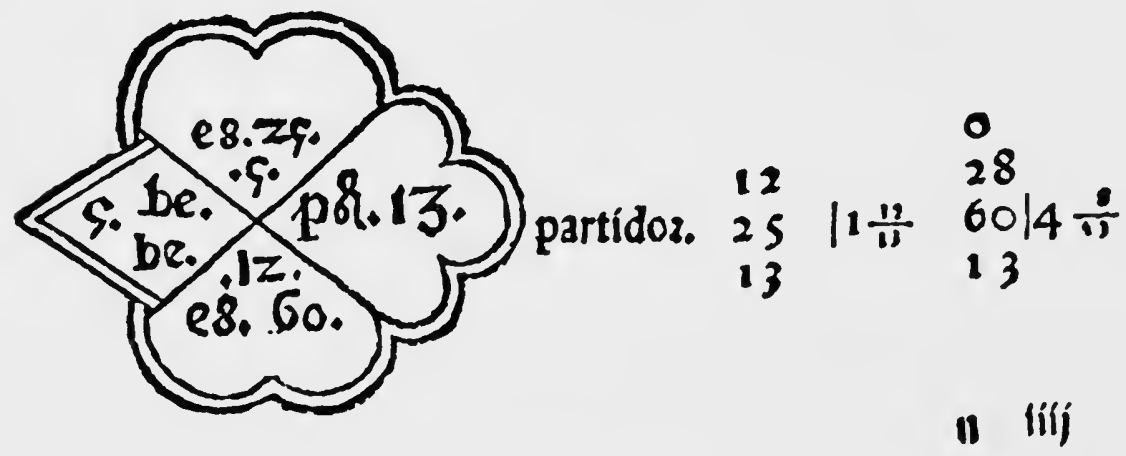


\section{Square Numbers}

\section{Eighth problem}

II 3 times 3 is 9,4 times 4 is 16 , and the sum of 9 and 16 is 25 , which is a square number having 5 for its root. Find two other numbers the sum of whose squares is 25 .

\section{近 Rule}

II Find 2 numbers whose squares added together will make a square having an integral root. Take 5 and twelve whose squares are 25 and 144 ; these added together make 169 , the root of which is 13 . Observe that in the previous problem similar to this one you had 5 numbers. Here you have 4 . The reason is that 3 and 4 , the first numbers, have an integral root which is 5 , which is one of the 4 numbers here, and serves for the 3 and 4 of which it is the root; the others are 5 and 12 , the assumed or presupposed numbers, and their root is 13 . Put them down as you see below; then taking the root derived from 3 and 4 , the first numbers, say " 5 times 5 is 25 , and 5 times 12 is 60 "; divide each product by 13 , which is the root of the sum of the squares of the proposed numbers, and the quotients will be the required numbers. Dividing 25 by I 3 , the result is $1 \frac{12}{13}$, which is the one part; dividing 60 by 13 , the result is $4, \frac{8}{13}$; square each quotient and add the results and the sum will be 25 as required. That is, $1 \frac{12}{13}$ squared is $3 . \frac{11}{169} ; 4, \frac{8}{13}$ squared is $21 . \frac{51}{169}$; and their sum is 25 , as you see by the work.*

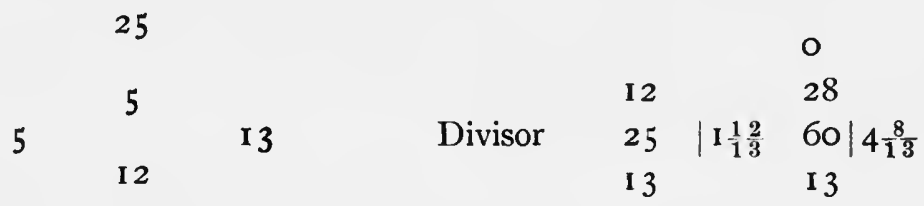

60

* This is simply a variant of the seventh problem. Euler's general solution, referred to on page 47 , applies to the equation $x^{2}+y^{2}=f^{2}+g^{2}$. If $f=3$ and $g=4$, as in this case, the solution is

$$
x=\frac{8 p q+3\left(q^{2}-p^{2}\right)}{p^{2}+q^{2}}, y=\frac{6 p q+4\left(p^{2}-q^{2}\right)}{p^{2}+q^{2}},
$$

where $p$ and $q$ may have any values whatsoever. 


\section{Thotables. Quiftiones.}

\section{Geuiftiones oclartomaroz tocantcs alalgebra. \\ Ifoumera quiltioin.}

Tog me on numero quadrado que reltando oel, $15,2, \frac{3}{4}$ queoc fu p:opzia razz.

ITRegla.

Goigo que el numero fea bna cold oemediala es media cofa inulti plica la en li baze $\frac{1}{4}$ oezenfoajultale $a, 15,2 \frac{1}{4}$ bajze, 16 , cupa raqz quadrada z illas el imedio och cofa es rapz oel nuincro oemâdado q) sueua quadia raqz quadrada oe.1 6.2 miascl nicdio obla coia qa cs:

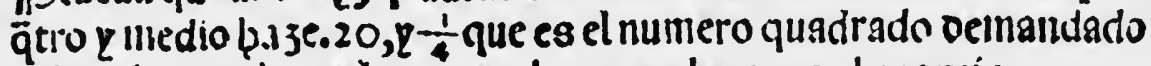
reftadel $, 15, x \cdot \frac{1}{4}$ quedin, $4,2 \frac{1}{2}$ que es la rapz oel $p: o p z i$.

G. Segunda quiftion.

TEs ono que fe fleta en on nauio $x$ pregunta al maeftre que es lo que ba : a dar oe fleteel maettre oije que no le ba de lleuar nas q alos otros boluiendoel paffajero a replícar quanto fería el maeftre refponde que pan oe fer tantos pefos que multiplicados poz fi i g puitando los alo produto el remanente $\mathrm{Ter}_{2}, 1200,0 \mathrm{emando}$ quan= to ocmianda el maeftre.

\section{TiRegla.}

Tा wigo que el flete fea pna cofa oe pos. La mítad es media cofa qua

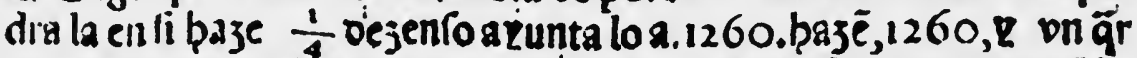
to rap 3 oclos quales inenos medío dela cofa cs cl numero ocinäda do ocl flete:reduce, $1260,2 \frac{1}{4}$ \& quartos foll so41 la ray 3 C8.71, me dios relt a cl inedio dela cofa que es medio quedan, 70 , mèdíos que fon, $35, j 3$ y tanto cs lo q̃ ocinäda ocl flete: 2 zueus multíplica.35.

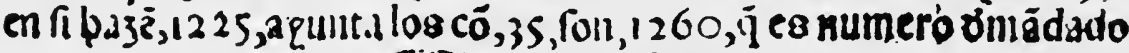
(1) Esrcero quiftion.

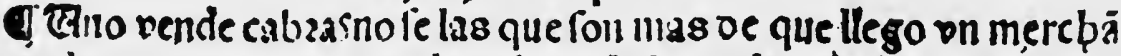
te p. le p.cgunta quantas abra el vendedoz relponde fon tantas que fi las inultiplear 8 en fi y lo produto quadruplazs el vltíno produzi do fers, y0000, oemandoquantas cabzso tenta. 


\section{Noteworthy Problems}

đII Problems of the Arte Mayor, relating to algebra

$\mathbb{1}$ First problem

[I Find a square from which if $15 \frac{3}{4}$ is subtracted the result is its own root.

बII Rule

$\mathbb{1}$ Let the number be $\cos a(x)$. The square of half a cosa is equal to $\frac{1}{4}$ of a $z e n s o$ $\left(x^{2}\right)$. Adding 15 and $\frac{3}{4}$ to $\frac{1}{4}$ makes 16 , of which the root is 4 , and this plus $\frac{1}{2}$ is the root of the required number.*

Proof: Square the square root of 16 plus half a cosa, which is four and a half, giving 20 and $\frac{1}{4}$, which is the square number required. From $20 \frac{1}{4}$ subtract 15 and $\frac{3}{4}$ and you have 4 and $\frac{1}{2}$, which is the root of the number itself.

\section{तl Second problem}

II A man takes passage in a ship and asks the master what he has to pay. The master says that it will not be any more than for the others. When the passenger again asks how much it will be, the master replies: "It will be the number of pesos which, multiplied by itself and added to the number, will give 1260." Required to know how much the master asked. $\dagger$

\section{बI Rule}

$\mathbb{\mathbb { I }}$ Let the price be a cosa of pesos. Then half of a cosa squared makes $\frac{1}{4}$ of a zenso, and this added to 1260 makes 1260 and a quarter, the root of which less $\frac{1}{2}$ of a $\cos a$ is the number required. Reduce 1260 and $\frac{1}{4}$ to fourths; this is equal to $\frac{50.1}{4}$, the root of which is $7 \mathrm{I}$ halves; subtract from it half of a cosa and there remains 70 halves, which is equal to 35 pesos, and this is what was asked for the passage.

Proof: Multiply 35 by itself and you have 1225 ; adding to it 35 , you have I 260, the required number.

\section{बI Third problem}

II A man is selling goats. The number is unknown except that it is stated that a merchant asked how many there were and the seller replied: "There are so many that, the number being squared and the product quadrupled, the result will be 90,000." Required to know how many goats he had. $\ddagger$

* $x^{2}-15^{\frac{3}{4}}=x, x^{2}-x+\frac{1}{4}=16, x=4 \frac{1}{2}$, the negative root being neglected. Cosa (thing) was the unknown $(x)$, and zenso (Latin census) was our $x^{2}$.

$\dagger x^{2}+x=1260$, whence $x=35$.

$\ddagger 4 x^{2}=90,000$, whence $x=150$. 


\section{Delarte. ADayo?.}

fo.ci.

CitRegla,

4 Digo que tenga pna cofa de cabsas multíplica en n baze on jen fo multiplica el zenfo po2, 4, que ce quadruplo beje 4 , senfos r gua le 8.900 oo.cab 298 q $e 8$ numero parte numero poz cenfo el adue múniento es, 22250. rąz delos qualcs fon las cabzas q̀ tenia. Diue wA ton:d, 150, ralj3 Oe.22250.multiplica en fi bazen, 22250 .multt. plica los p0:, 4,que es quadruplallo fon.90000.

TQuarta quiftion. G. Cono va pos vn camino pacgunta a otro que leguas aula bafta vo na cicrta parte el otro le refponde ą tantas leguas que fi las multí plicaps en fi v lo pzoduto partís poz, $5, \mathrm{cl}$ aduenimiento $\mathrm{era.80.0e=}$ mandado que leguas sbza enlo que rrize.

At Reglo.

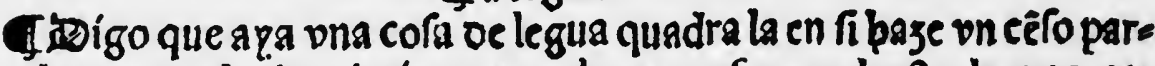
tele p02.5. el aduenimíentocs $\frac{1}{5}$ oe cenfo p.gual a.80.leguas par te nuinero poz cenfo que e8.80.por $\frac{1}{5}$ el aduenimiento.cs.400.cu La ra 23 fon las leguas que aq:pues multiplíca ray3 oe. 400 .en fi $\tilde{q}$ e8.20, y lo produsido parte p02.5.el adueníniento fera.80.numero Deinandado.

TQuinţa quiftion.

A Eno coinpza ropa oel a tierra en tripla pzopozcion oe tal fiverte à multiplicando el triple pas el quarto oel fu tríple que fon las pieças oe ropa que compzo lo pzoduto fera, 48 .pefos oemando que pieças oe ropa compzo.

GrRegla.

T. pa que es en trípla propozcion óc ropa inultiplíca vil qual to re co= fa oc piç̧a de ropa p02,3.coras de pefos cs $\frac{1}{4}$ oecenfo pguales a 48:pefos que es numero parte numero poz céfo que $68.4 \&$. fc: $\frac{3}{4}$ eleduenuníento e8,64.ralz oclos quales fon las pieças oe ropa ä 


\section{On Algebra}

तI Rule

II Let a cosa represent the number of goats. Squaring this we have a zenso; multiplying the zenso by 4 , which is a quadruple, makes 4 zensos, which is equal to 90,000 goats. Divide 90,000 by the number of zensos, and the quotient is 22,500 [not 22,250 as given], the root of which is the number of goats he had.

Proof: Square 150, the root of 22,500, and you have 22,500; multiply this by 4 , which is quadrupling it, and you have 90,000 .

\section{Fourth problem}

II A man traveling on a road asks another how many leagues it is to a certain place. The other replies: "There are so many leagues that, squaring the number and dividing the product by 5 , the quotient will be $80 . "$ Required to know the number of leagues.*

\section{đII Rule}

IILet a cosa represent the number of leagues. This squared makes a zenso; and this divided by 5 equals $\frac{1}{5}$ of a zenso, which is equal to 80 . Divide 80 by $\frac{1}{5}$ and the quotient is 400 , whose root is the number of leagues required.

Proof: Multiply the root of 400 , which is 20 , by itself. Then divide the product by 5 and the quotient is 80 , the number required.

\section{$\mathbb{1}$ Fifth problem}

II A man buys a number of pieces of clothing for three sums of pesos which are in triple proportion, so that multiplying the triple of the first by $\frac{1}{4}$ of the number tripled, $\uparrow$ which is the number of pieces of clothing, the product will be 48 pesos. Required to know how many pieces of clothing he bought. $\ddagger$

\section{近:Rule}

đI Let a cosa of pieces of clothing be bought for three cosas of pesos in triple proportion to the pieces of clothing. Multiply a quarter of the number of pieces of clothing by 3 cosas of pesos and you have $\frac{3}{4}$ of a zenso, equal to 48 pesos. Divide 48 by $\frac{3}{4}$ and the quotient is 64 , the root of which is the number of pieces of clothing

$* \frac{1}{3} x^{2}=80$, whence $x=20$. † That is, $3 x \times \frac{2}{4} x . \quad \ddagger \frac{3}{4} x^{2}=48, x=8$. 


\section{Quiftiones.}

ex'np:0 coft aron le el triple que es ray 3 oe, 676 , cjrinzjoe, 676, que e8, 24 ,poz.2. que e8 el $\frac{1}{4}$ oel fu triple oe rra i. de, 54 , el dduenimiento e8,48, numero ocinandado.

\section{G5erta quiltion.}

4. Cno tiene reguas y vaczs en quíncuplaproporcion oe talfucte que fi multiplicas las zeguas en fi q las vacas en fi q lo produto fus Imas leran,i69 t, De.ñ do äntas fó las leguas quantas las racas. if Regla.

IT igo que tenga pra cofa de reguas 2,5 , cofas oe vacas mulís plica vna cofa en li baze vil cenfo mul. 5. cofas en fi bazen, 25 , cêtos atunta lo. Ton.26.cenfos \& guales a, 1664 , le guas q vacas nume $=$ ro oemandado parte numero poz cenfo que $\mathrm{C8}, 1064,902,26, \mathrm{el}$ ad= uenimiento 83,64 , cuqa rayz 3 fon las reguas $\mathrm{L}$ el quincuplo las $\mathrm{va}=$

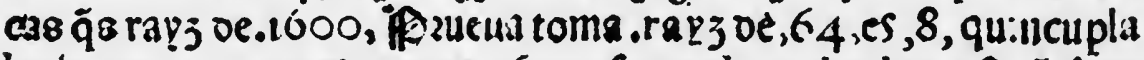
lospazen, $40, q u e$ es rasz de, 1600 , fuma el quidrido oe, 8 , q fon las reguas con cl quadracio oe 40 , que forl lis racja brjê, 1664 , q̊fu: 10 ocinandidc.

GSetimaquirion.

CEnotienc tres ioqaв ẽ q̆drupla p:opoz:íó de valoz de tal mante ra que multiplic.nindo lo que vale la pzimera poz el valoz oela feguns daplo pzoduzído p'ozel valoz oela terceracl vltimo pzoducolera. 17.28, Deinando que co el valoz de cad a jous,

ofregla.

4. Digo que la puinera nalga una cora y la fegüda, 4 , coras q la ter cera, 6 , que como veps eftun en quadrupla propo:cion mul ina co

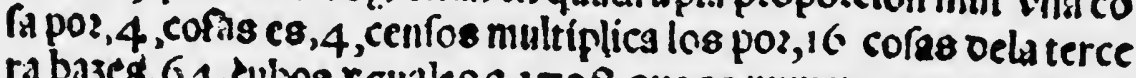
ra bajes, 64 , tubos rguales $\$, 1728$, que es mumiero parte nuincro por cuboel aduènimiento $\mathrm{e8}, 27$, cura razz $\mathrm{Cuba}$ que e8,3, e8 el va. loz Dels paimera r lafegunda vale raiz cuba oe.1.728, que es, 12, , La 


\section{Problems}

that he bought. They cost him three times this, which is the root of 676 [576].

Proof: Multiply the root of 676 [576], which is 24 , by 2, which is $\frac{1}{4}$ of its cube, that is, of 8 , the square root of 64 . The result is 48 , the number required.

\section{$\mathbb{\mathbb { N }}$ Sixth problem}

IIA man has mares and cows in quintuple proportion, in such a way that if you square the number of mares and square the number of cows, the products added will be 1664 . Required the number of mares and the number of cows.*

\section{$\mathbb{\mathbb { L }}$ Rule}

II Let there be a cosa of mares and 5 cosas of cows. Squaring the first makes a zenso, and 5 cosas squared makes 25 zensos, and the sum is 1664 mares and cows, the required number. Divide this number by the number of zensos, that is, divide 1664 by 26 . The quotient is 64 , whose root is the number of mares, and the quintuple, or square root of $\mathrm{I} 600$, is the number of cows.

Proof: Take the square root of 64 ; it is 8 . Quintuple it and you have 40 , which is the square root of 1600 . Add the square of 8 , the number of mares, to the square of 40 , the number of cows, and you have 1664 , which was required.

\section{$\mathbb{I}$ Seventh problem}

đI A man has jewels in quadruple proportion of value such that, multiplying the value of the first by the value of the second and the product by the value of the third, the last product will be 1728 . Required the value of each jewel. $\dagger$

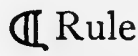

II Let the value of the first be one $\cos a$; that of the second, $4 \cos a s$; and that of the third, I6 cosas, which you see are in quadruple proportion. Multiply one cosa by 4 cosas and this is equal to 4 zensos. Multiply this by 16 cosas and the result is 64 cubes, and this is equal to 1728 . Divide this number (that is, 1728 ) by the cube (that is, by 64 ) and the quotient is 27 , whose cube root is 3 , the value of the first jewel. The second one is worth the cube root of 1728 , or 12 ; and the

$* x^{2}+25 x^{2}=1664$ (not 1694 as in the original), whence $x=8$.

† Take $x, 4 x, 16 x$. Then $64 x^{3}=1728$, whence $x=3$. 


\section{Delarte. ADaro?.}

fo.cii.

tereera vale, 48, que es rayz cubs oc, 2304, Trip rucua mul.el valo28 la puinera que e8,3,p0z cl ocla icgunda que es doze reladuenimié to pos la tcreera, que es,48, lo pzoduto delas multiplicacionesfera , 1728.

\section{Goctaua quiftion.}

4) Cno tiene bljos z bllas en p:opoxion fis que altera be talartea mul. los bijos poz las bijas z to produto coz la mitad oelos bijos el vltimo piodusído fera, 162 , ocinando quantos fon lcs bijos z qua. ths las bijus.

\section{Triegla.}

T. igo que los bifos fean rne cofa y las lijas rna cof́a y mcdia que es on fis que altera propoicion mul. ona cof́a por una cofa $x$ me dia es un cenfo y mrdio el qual niulifiplica for mcdía ccla que es ní tad oelos pijos bazes $\frac{3}{4}$ oecubo qguales 9,162 , bijos q bijas que. c8 numero parte numero pozcubo quec8,162. $\mathrm{pas} \frac{1}{4}$ el kducnimt

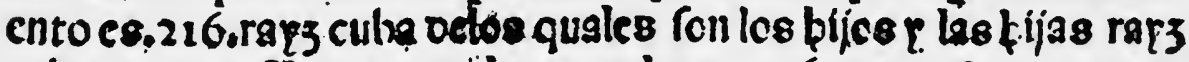
cuba oe, 729 , 1 grseua, mul, razz cubs oc, 216, que $c 5,6$, for ray 3 cu ba oe. 729 quece, 9 , pajen, 54 , los qualeo miul pos niccio ocieqs que fon los bijoo lo produto ce, 162 , que es el numero ocinendado.

\section{Gilloueraquiftion.}

TGino ba oe bazer 003 pagamentos çquaoupla propozció oc mc. fes en tal manera:q̃ quadrando el fu cu ddruplo q lo que falicre mull. poz el quaduplo r lo pzoduzido cubica ndo el t ltímo produjido fea. 32768 .Demando a quantos mefcs fon los paganicntos.

\section{TrRegla}




\section{On Algebra}

third is worth 48 , the cube (sic) root of 2304.

Proof: Multiply the value of the first, which is 3 , by that of the second, which is twelve, and this product by the value of the third, which is 48 , and the product of the multiplications is 1728 .

\section{Eighth problem}

II A man has a certain number of sons and daughters in altera proportion such that multiplying the number of sons by the number of daughters and the product by half of the number of sons, the last product will be $\mathbf{1 6 2}$. Required the number of sons and the number of daughters.*

\section{Rule}

II Let the number of sons be a $\cos a$, and the number of daughters be a cosa and a half, which numbers are in altera proportion. Multiply one cosa by a cosa and a half and the result is a zenso and a half, which multiplied by half a cosa, which is half the number of sons, makes $\frac{3}{4}$ of a cube which is equal to 162 , the number of sons and daughters. Divide this number by the number of cubes, that is, divide 162 by $\frac{3}{4}$, and the quotient is 216 , the cube root of which is the number of sons, and the cube root of 729 is the number of daughters.

Proof: Multiply the cube root of 216 , which is 6 , by the cube root of 729 , which is 9 , and the result is 54 ; multiply this by half of six, which is the number of sons, and the result is 162 , the number required.

\section{Ninth problem}

II A man has two payments to make, in quadruple proportion of months, so that squaring the first, multiplying the product by the quadruple, and cubing this product, the result will be 32,768 . Required to know how the payments were made. $\dagger$

* By the ancient Greek theory of proportion (ratio), ${ }_{2}^{3} x$ and $x$ are in altera proportion. The word proportion was commonly used for ratio in the sixteenth century, and the same is still the case outside the school. Take $x$ and $\frac{3}{2} x$. Then $\frac{3}{4} x^{3}=162$, whence $x=6$.

† $64 x^{9}=32,768$, whence $x=2$. 


\section{'filotables Quiftionce,}

ItRegla.

Treigo que lo8.2.pagamentos fean ona cofa z. 4.cofas que es cua drupla pzopozcion qusdrs elfu quadraplo es vn cenfo multiplica le pozel quadruplo e8. 4. cubos cubicalos aze8.64.cubos be cub08 zguales a. 32768. que es numero: arte numero $p o z$ cubos oe cubos que e8, 32768. po2, 64, el aduenimiento es.512, cula ra= za cuba oe rarz cuba feran los mefes oel paimer pagamento z rars

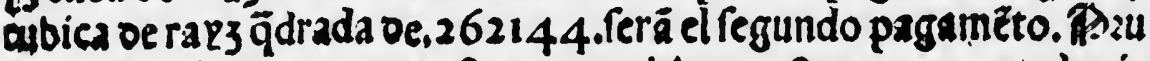
eudirap3 cubica oc. 512.e8.8. 2 razz cubica oe.8.e8.2.que es el pzis mer plazo: 2 razz ఫ̄drada oe. 262144 .es. 512.2 rapz cubica De. 512. e8. 8. que es el fegundo plajo:quadra el. 2.q̄ es fu quadruplo oe.8. e8.4.el qual multiplíca por el quadruplo es.32. cubícalos el vltimo produzido e8.32768. numero oemandado.

Ifoezena quiftion.

Gan bombzc tiene ona bijos en pzopozciñ fis que quarta 8 bedad eir tal manera que, inul.el fu quadruplo oela bedad oel inenos poz el ru quincuplo oela bedao oel mazer 2 lo que faliere quadruplando 2 o elo produzido facādo fu razz r cubícãdo la mitad cl vltíno pzodu zido fera.125.años:oemando que bedad tiene cada vno.

\section{Gifiegla.}

Goigo que el menoz aya vna cofa ocańns yel maroz ayg. vna cofa p. $\frac{1}{4}$ oe cofa de años que es fis que quarta pzoporció, muleelfu quadriplo del menoz poz cl fu quíneuplo ocl imaqoz quecs $\frac{1}{4}$ por $\frac{1}{4}$ lo produto es $\frac{1}{16}$ oe cenfo quadrupla $\frac{1}{16}$ es $\frac{1}{4}$ oe cenfo fu rayj esmedia cofa cubica fu mitad que ce vn ärto oe cofa el viti moproduzldoes $\frac{1}{64}$ oe cubo rgual 2.125. que es lo que re burca pte mimero poicubo que e8.125.poz $\frac{1}{54}$ el aduenillitiento c8. 8000, cuy ' razz clubica fon los aítos del menoz y rar 3 quadrada de. 625 . fon los oel hildroz. fiesueua toma rarz cuba oe. Sooc.bedad del me noz e8.20. mul.el fu quadi uplo que 68.5 poz cl fu quíneuplo oe.25. rą3 quadrada oe.625.que e8.5.lo produto e8.25.quadiuplalos ba 


\section{Noteworthy Problems}

\section{Rule}

II Let the 2 payments be represented respectively by one cosa and $4 \cos a s$, which are in quadruple proportion. Square the first, making a zenso; multiply this by the quadruple, giving 4 cubes ; cube this, making 64 cubes of cubes equal to 32,768 . Divide 32,768 by 64 and the quotient is 512 , of which the cube root of the cube root is the number of months for the first payment. The cube root of the square root of 262,144 will be the number of months for the second payment.

Proof: The cube root of 512 is 8 , and the cube root of 8 is 2 , which is the number of months for the first payment. The root of 262,144 is 512 , and the cube root of 512 is 8 , which is the second number of months. Square the 2, which is a fourth of 8 , and this is equal to 4 , which, multiplied by the quadruple 8 , is equal to 32 . Cube 32 , and the result is 32,768 , the required number.

\section{$\mathbb{I}$ Tenth problem}

II A man has two sons whose ages are in such a quarta proportion that, multiplying one fourth of the age of the younger by one fifth of the age of the elder, and quadrupling the result, and cubing half the root, the final product will be 125 years. What is the age of each ?*

\section{đII Rule}

III Let the age of the younger be a cosa of years and that of the elder be a cosa and $\frac{1}{4}$ of a cosa of years, which is a quarta proportion. Multiply a fourth of the younger by a fifth of the elder, which is $\frac{1}{4}$ by $\frac{1}{4}$. The product is $\frac{1}{16}$ of a zenso. Now quadruple $\frac{1}{16}$, and this is equal to $\frac{1}{4}$ of a zenso, of which the root is half a cosa. Cube half of this and the product, $\frac{1}{64}$ of a cube, is equal to 125 . Divide 125 by $\frac{1}{64}$ and we have 8000 , whose cube root is the number of years in the age of the younger, and the square root of 625 is the number of years in the age of the elder.

Proof: The cube root of 8000 is 20 , the number of years in the age of the younger; multiply a fourth of it, or 5 , by a fifth of 25 , the square root of 625 , which is 5 , and the product is 25 ; and this multiplied by 4 (that is, 25 being quadrupled)

* He means to multiply by $\frac{1}{4}$ instead of 4 , and $\frac{1}{5}$ instead of 5 . That is, the age of the younger is $x$; of the elder, $\frac{5}{4} x$. Then $\frac{x}{4} \cdot \frac{\mathrm{I}}{5} \cdot \frac{5 x}{4}=\frac{x^{2}}{16} ; 4 \times \frac{x^{2}}{16}=\frac{x^{2}}{4} ; \sqrt{\frac{x^{2}}{4}}=\frac{x}{2} ; \frac{\mathrm{I}}{2} \cdot \frac{x}{2}=\frac{x}{4} ; \frac{x^{3}}{64}=125$,
whence $x=20$. 


\section{Dearte mayor. fo, ciii.}

jen ciento, toma la mitad de fu razz e8 as. cubicalos el vltimo produ jijoe8.125. numcro ocimandado lo qual nota.

TiAlo be querido fer enefto mas largo lo mo poz euitar pzolíídad y lo otro po:quic como frempze be oicb o mi entento nunca fue otro que policr las cofas neceflarias enel comun oeftos repgnes:p affi verera conno enlo de inas be fido bzcu e fuplíco os, fea tomado êfCr uicio e reccbida la voluntad como of quíen oeffea feruir.

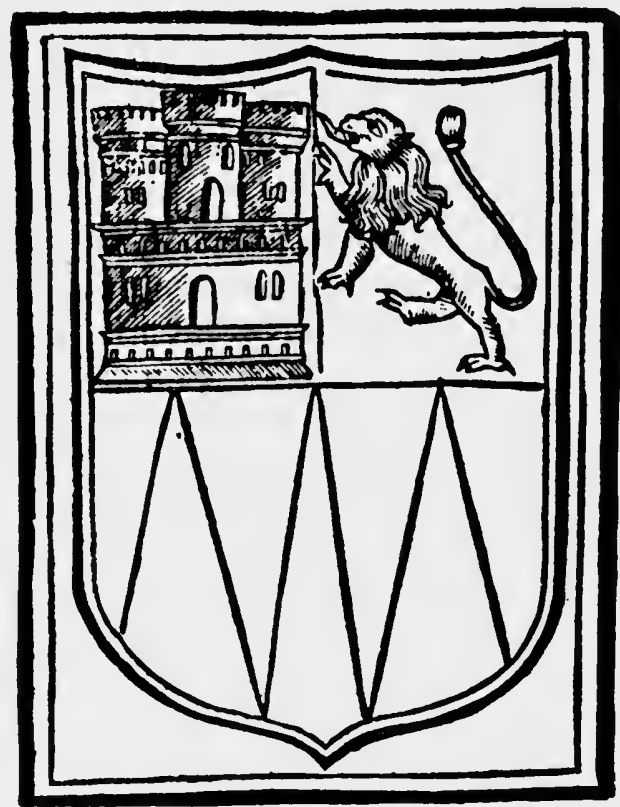




\section{On Algebra}

makes a hundred. Take half of the root of 100 , which is 5 ; cube this, and you have I 25, the number required, which note carefully.

III It has not been my desire to extend this work, one reason being that I would avoid becoming tiresome, and the other reason being, as I have always said, that I have wished merely to set down the things which are necessary and familiar in this kingdom. You will therefore see that I have always written succinctly, and so I beg that this book may be judged and received merely as the work of one who seeks to be of service to his fellows. 


\section{finoelaobra.}

If Ilbonria y glozia oe nio feño2 3efu

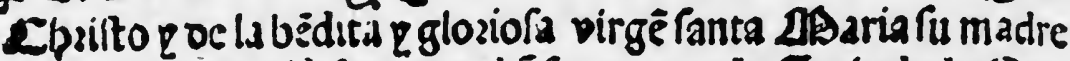
q lefiosa nra. êlá feaczba el p pente tratado 3 ntitulado \$u mario cópindiolo oe cuêtas de plata q oeonceeffarias en los rernos ocl Bjiru. El qual fuc impzefto en la mur grande guligne q muz lical ciudad oe 2 serico, en cafa oc Yुuan pablos BB:effano : con licencía oel

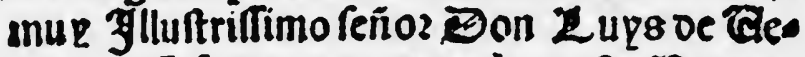

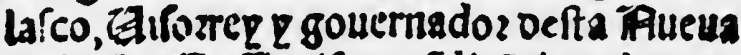
efpaña. Eafti nifino có lícēcla del muz 3̆lluftrc $q$ reuerẽdiffimo. S.Dó.frat âlölo de abótufar arçobifpo de mepico:por änto fue vilto r epas minado, re ballo fer puecbo roimpzinirfe, Ileabofe oe impimir:a veqnte 2 nue ue otas del imes oe Abaro. Il cimiēto de nío Serioz Yelu Ebatito. 8.1556 sก்̃

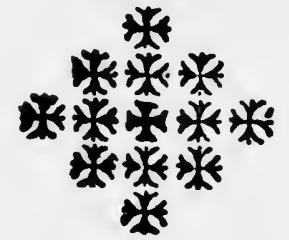




\section{End of the work}

\section{To the honor and glory of our Lord Jesus Christ}

and the blessed and glorious Virgin Holy Mary, His mother and our Lady. This is the end of this treatise entitled Sumario cõpendioso of the computations of gold and silver necessary in the Kingdoms of Peru. This was published in the magnificent, famous, and most loyal City of Mexico, in the house of Juan Pablos Bressano; with the permission of the illustrious señor Don Luys de Velasco, Viceroy and Governor of New Spain and, also, with the permission of the most illustrious and reverend señor, Brother Alonso de Montufar, archbishop of Mexico, by whom this has been seen and examined and found worthy to be printed. The printing was finished on the twenty-ninth day of the month of May in the year of our

Lord Jesus

Christ I 556

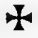
世中出 世正出士 平为 $\Psi$ 
, 


\section{INDEX}

PAGES PAges

Abbreviations of monetary units . 9-1 I Mendoza . . . . . . . . . . 3

Algebra . . . . . . 8, I5, 5 I-6 I Mexico founded . . . . . . . 3

Alonso (Alphonso) de Montufar . 3,63 Montufar . . . . . . . . . 3, 33

Antonio de Mendoza . . . . . . 3 Multiplication . . . . . . . . 29

Arte mayor . . . . . . . I5, 5 I

Bibliography . . . . . . . 5,6

Pablos . . . . . . . $3,5,63$

Books printed before 1557 . $. \quad . \quad .5,6$ Per cents . . . . . . . . . . . . . I I

Peso . . . . . . . . . 9

Cardan . . . . . . . . . 8 Printing in Mexico . . . . . . . 3,5

Census . . . . . . . . $5^{\mathrm{I}}$ Problem of the weights . . . . 47

Common rules . . . . . . . 15

Congruent numbers . . . . 4I, 43,45 Real . . . . . . . . . . . 9

Congruous numbers . . . . 4I, 43, 45 Reduction of money . . . . . 23

Congruum . . . . . . . . . $4 \mathrm{I}$ Root for square root . . . . . . 37

Cortés . . . . . . . . . . 3 Rule of Three . . . . . . . 39

Cosa . . . . . . . . $5^{\mathrm{I}}$

Cromberger . . . . . . . 3

Cuento . . . . . . . . 9

Sumario printed . . . . . 5,6

Tables . . . . . . . . . . . 9

Fibonacci . . . . . . . . . $4 \mathrm{I}$ Tenochtitlan . . . . . . . . 3

Text . . . . . . . . . 13

Grain . • • • . • . . . . I I

Tomin . . . . . . . . . 9, I I

Grano . . . . . . . . . . I I

Juan Cromberger . . . . . 3, 5

U for 1000 . . . . . . . . . I I

Juan Diez . . . . . . . . . 7

Juan Pablos . . . . . . . . . $3,5,63$ Vander Hoecke . . . . . . . . . 8

Juan de Zumárraga . . . . . . . 3, 5 Vara . . . . . . . . . . . . II

Velasco . . . . . . . 3,63

Leonardo Fibonacci . . . . . 4 $4 \pi$

Luys de Velasco . . . . . . $\quad 3,63$ Weights, problem of . . . . . . 47

Maravedi . . . . . . . . 9, I I Zenso . . . . . . . . . . 5 I

Mariani . . . . . . . . . 7 Zumárraga . . . . . . . . . 3,5 




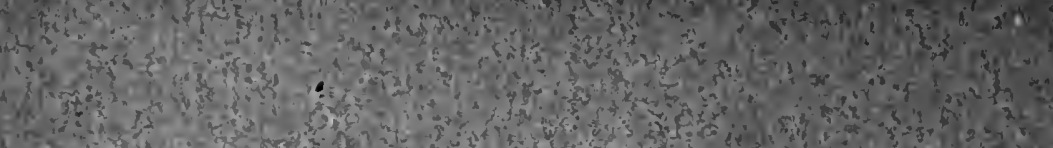

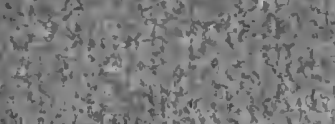

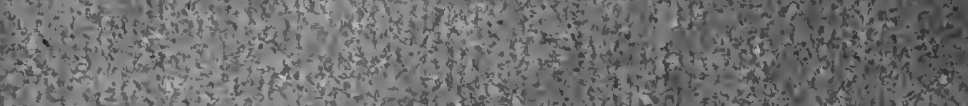

and

(n)

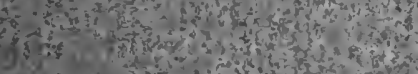

3
3 